\title{
ENVIRONMENTAL ASSESSMENT FOR THE NATURAL FLUCTUATION OF WATER LEVEL IN PAR POND AND REDUCED WATER FLOW IN STEEL CREEK BELOW L-LAKE AT THE SAVANNAH RIVER SITE
}

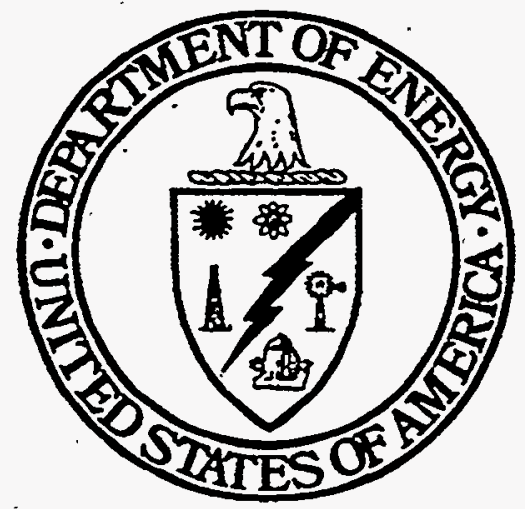

AUGUST 1995

UNITED STATES DEPARTMENT OF ENERGY SAVANNAH RIVER OPERATIONS OFFICE SAVANNAH RIVER SITE 


\section{TABLE OF CONTENTS}

SECTION

PAGE

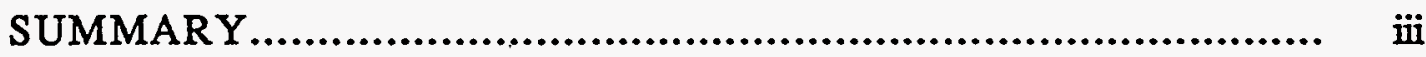

1.0 INTRODUCTION......................................................... 1

1.1 Purpose and Need For Action................................................ 1

$1.2 \quad$ Background................................................................. 1

1.2.1 River Water System......................................................... 1

1.2.2 .Par Pond........................................................... 3

1.2.3 L-Lake.......................................................... 9

1.2.4 Flows in Steel Creek below L-Lake Dam................................. 9

2.0 PROPOSED ACTION AND ALTERNATIVES....................................... 11

2.1 Proposed Action................................................................... 11

2.1.1 Par Pond ........................................................ 11

2.1.2 L-Lake (Steel Creek flows)............................................. 14

2.2 Alternatives to the Proposed Action................................................. 14

2.2 .1 No Action............................................................ 14

2.2.2 Reduce Pumping to Par Pond and Allow Flucctuating Water Levels and Continue to Maintain a $53 \mathrm{ft}^{3} / \mathrm{sec}$ Flow in Steel ......... 15

2.2.3 Continue Pumping to Par Pond and Reduce Discharge to Steel Creek from L-Lake from $53 \mathrm{ft}^{3} / \mathrm{sec}$ to $10 \mathrm{ft}^{3} / \mathrm{sec}$....................... 15

3.0 ENVIRONMENTAL CONSEQUENCES OF THE PROPOSED ACTION AND ALTERNATIVES......................................................... 15

3.1 Par Pond and Lower Three Runs............................................ 15

3.1.1 Par Pond............................................................ 15

3.1.2 Lower Three Runs ${ }^{-}$.............................................. 21

3.2 L-Lake and Steel Creek...................................................... 22

3.3 Monitoring Par Pond Water Level and L-Lake/Steel Creek Flow Reduction............................................................... 23

3.4 Environmental Consequences of the Alternatives.................................. 24

3.5 Other Impacts................................................................ 25

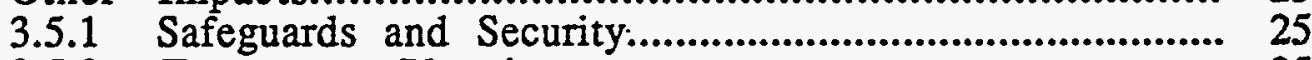

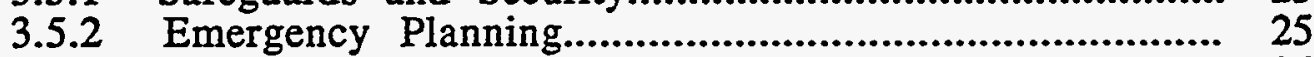

3.6 Cumulative Impacts.............................................................. 25

4.0 REGULATORY AND PERMITTING CONSIDERATIONS........................ 25

4.1 National Environmental Policy Act of 1969, as Amended -

(42 USC 4321 et seq.).......................................................... 25

4.2 Wetland Regulations.......................................................... 26

4.3 Drinking Water Regulations....................................................... 26

4.4 Navigable Water Regulations...................................................... 26

4.5 Clean Water Regulations........................................................... 26

4.6 Clean Air Regulations............................................................. 27 
4.7 Comprehensive Environmental Response, Compensation and Liability Act (CERCLA) Waste Regulations..............................................

5.0 REFERENCES.

\section{LIST OF FIGURES}

Figure 1. Location of the River Water Distribution System Between the 1G, 3G, and 6G Pumphouses on the Savannah River, Par Pond, and L-Lake at the Savannah River Site, South Carolina.

Figure 2. Exposed Sediment Areas in Par Pond at the $54 \mathrm{~m}(181 \mathrm{ft})$ level and the P- and R-Reactor Water Distribution System.................................... 4

Figure 3. Map of L-Lake and Steel Creek............................................. 10

Figure 4. Exposed sediment areas in Par Pond at the $58.2 \mathrm{~m}$ (195 ft) level and the P- and R-Reactor water distribution system......................................

Figure 5. Estimated acres of exposed sediment and frequency of submergence for predicted (i.e., modeled) and actual fluctuating water levels in Par Pond (Based on USCOE, 1994). 


\section{SUMMARY}

The DOE needs to take action to reduce unnecessary operating expenses at the Savannah River Site. The Savannah River Operations Office Strategic Plan directs SRS to find ways to reduce. operating costs, and to determine what site infrastructure must be maintained and what infrastructure is surplus. Because of the mission change, L-Lake, Par Pond, and the river water system are no longer needed to support current missions and therefore provide an opportunity for operating cost reduction. If SRS determines that L-Lake, Par Pond, and the river water system are no longer needed to support future missions and are considered surplus, appropriate NEPA documentation will be prepared.

The purpose of the proposed action in this Environmental Assessment is to begin an examination of the need for the Site's river water system by (1) developing data needed to evaluate the potential environmental impacts of further reducing or eliminating the flow demands from the Site's river water system and; (2) evaluating the potential of reducing operating costs by allowing the water level in Par Pond to fluctuate naturally through reduced pumping. This action also includes reducing the current flow rates from L-Lake to Steel Creek to natural stream flows while maintaining full pool.

The recently approved Par Pond CERCLA Interim Action Proposed Plan (IAPP) committed to evaluate in a NEPA document the environmental consequences of this proposed action. This document evaluated the remediation of human health and ecological risks associated with the three year drawdown of Par Pond. Should any of the parameters sampled in the reservoir and streams (e.g., water quality, biota, etc.) exceed established threshold levels during the implementation of the proposed action, water would again be pumped into the reservoir to minimize any impacts by bringing the water level back to an appropriate level above $58.2 \mathrm{~m}(195 \mathrm{ft})$.

Par Pond is a 2,640 acre recirculating cooling water created in 1958 by the construction of an earthen dam on Lower Three Runs. Par Pond was used to dissipate heated effluents from both Pand R-nuclear production reactors. The 1,000 acre L-Lake, created in 1984, was used to dissipate heated effluent from L-Reactor. R-Reactor ceased operation in 1964 and P- and L-Reactor ceased operation in 1988.

Par Pond was drawn down in 1991 from about $5.7 \mathrm{~m}$ (19 ft) from $60 \mathrm{~m}$ to $54.3 \mathrm{~m}$ (200 ft. to 181 $\mathrm{ft}$. msl) due to depression on the slope of the earthen dam. Par Pond remained lowered at twothirds of its original volume for more than three years while the dam was being prepared. The drawdown exposed 1,340 acres of sediments contaminated with Cs-137 and mercury and impacted the reservoir's ecosystem. Potential impacts of the proposed action in the EA were compared to impacts measured during the drawdown. The reservoir was recently refilled under a CERCLA interim action to reduce the risks.

The proposed action and preferred alternative is to reduce pumping to Par Pond and allow the water level to fluctuate naturally between full pool and $58.2 \mathrm{~m}(195 \mathrm{ft})$. This would have an impact on the reservoir's ecosystem through a reduction in nutrients from the Savannah River. This would lower Par Pond's productivity, species composition and relative abundance, and potentially increase Cs-137 uptake. The reservoir's ecosystem is expected to revert to that typically found in the southeast.

Under the no action alternative, SRS would continue to pump water from the Savannah River to Par Pond to keep the reservoir level at full pool. The water level would shield all the Cs-137 in the reservoir's sediments thus eliminating potential risks from exposed sediments. This action would also allow the continuing recovery of the reservoir's ecosystem similar to its previous 33 years of 
stable conditions before drawdown. Continuous pumping of nutrients from the Savannah river would assure continued high productivity and diverse species composition and relative abundance. No action also includes continuing to pump river water to L-Lake to maintain full pool and maintain the current $1.5 \mathrm{~m}^{3} / \mathrm{sec}\left(53 \mathrm{ft}^{3} / \mathrm{sec}\right)$ in Steel Creek. The total estimated electrical annual pumping cost of the no action alternative is $\$ 930,000$.

Two other alternatives were also evaluated. One would eliminate pumping to Par Pond while continuing to maintain a $1.5 \mathrm{~m}^{3} / \mathrm{sec}\left(53 \mathrm{ft}^{3} / \mathrm{sec}\right)$ flow in Steel Creek below L-Lake. This would save about $\$ 360,000$ in pumping electrical costs annually and would not allow continued recovery of the Par Pond ecosystem to pre-drawdown conditions. This would create a less productive reservoir which would be similar to other reservoirs in the southeast.

The other alternative would continue to pump river water to Par Pond but reduce the discharge to Steel Creek from L-Lake from $1.5 \mathrm{~m}^{3} / \mathrm{sec}\left(53 \mathrm{ft}^{3} / \mathrm{sec}\right)$ to $0.28 \mathrm{~m}^{3} / \mathrm{sec}\left(10 \mathrm{ft}^{3} / \mathrm{sec}\right)$ saving about $\$ 570,000$ in annual pumping costs. The potential environmental impacts would be about the same as for the no action alternative as reducing the flow in Steel Creek to base flow conditions is not expected to have any significant impact on the stream biota.

For the proposed action, the littoral vegetative community and other species such as fish would be impacted in the wave-wash zone. This approximately 115-acre area above $59.7 \mathrm{~m}$ (199.2 ft) represents only about 4.6 percent of the reservoir's total bottom area below full pool $(2,640$ acres) and about 20 percent of the bottom area between $58.2 \mathrm{~m}(195 \mathrm{ft})$ and full pool, the maximum projected fluctuation. Potential risks to human health or wildlife from Cs-137 in exposed sediments is expected to be insignificant because little impact was shown as a result of three year drawdown to the $54 \mathrm{~m}$ (180.2 ft) level.. Only one third of the Cs-137 inventory of previously exposed sediments is above about $56.7 \mathrm{~m}(189.2 \mathrm{ft})$ level, and the reservoir should not fluctuate. below the $58.2 \mathrm{~m}(195 \mathrm{ft})$ level.

As part of the proposed action, the reduction in current flow to Steel Creek from L-Lake from 1.5 $\mathrm{m}^{3} / \mathrm{sec}\left(53 \mathrm{ft}^{3} / \mathrm{sec}\right)$ to $0.28 \mathrm{~m}^{3} / \mathrm{sec}\left(10 \mathrm{ft}^{3} / \mathrm{sec}\right)$ is not expected to cause any impacts on the balanced biological community in Steel Creek based on accepted in situ instream flow studies.

The total electrical cost savings from reduced pumping by the proposed action is estimated at about $\$ 930,000$ annually with a reduction in Site electrical use of about 2 percent. 


\subsection{INTRODUCTION}

This Environmental Assessment (EA) has been prepared by the Department of Energy (DOE) at the . Savannah River Site (SRS), Aiken, South Carolina (Figure 1). The purpose is to assess the potential environmental impacts of allowing the water level in Par Pond to fluctuate naturally and to reduce the current required flow rate of 1.5 cubic meters per second $\left(\mathrm{m}^{3} / \mathrm{sec}\right)$ [53 cubic feet per second $\left(\mathrm{ft}^{3} / \mathrm{sec}\right)$ ] in Steel Creek at Road A below the L-Lake Dam to a minimum flow rate of about $0.28 \mathrm{~m}^{3} / \mathrm{sec}\left(10 \mathrm{ft}^{3} / \mathrm{sec}\right)$ continuous discharge from the dam. This proposed action develops data needs which may be used to support further studies involving the Site's water system including evaluation of the potential environmental impacts of further reducing river water pumping and thus reducing operating costs. River water pumping has created long term hydrologically stable and highly productive ecosystems with diverse populations of aquatic and wildlife species in both $\mathrm{Par}$ Pond and L-Lake reservoirs.

Continuing to pump river water to maintain full pool levels in both reservoirs and provide greater flows than may be necessary to Steel Creek and Lower Three Runs is not economical and may not be necessary to maintain these water bodies as area natural resources, particularly Par Pond. The option to reduce pumping water from the Savannah River to Par Pond and allow the water level to fluctuate naturally as well as reducing the pumping of river water to L-Lake (still maintaining full pool) is proposed as a prudent action. This option also includes reducing the flow to the minimum flow necessary to maintain water quality suitable for a balanced biological community in Steel Creek below L-Lake Dam:

\subsection{Purpose and Need for Action}

The DOE needs to take action to reduce unnecessary operating expenses. The Savannah River Operations Office Strategic Plan (DOE, 1994b) directs SRS to find ways to reduce operating costs and to determine what site infrastructure must be maintained and what infrastructure is surplus. Because of the mission change, L-Lake, Par Pond, and the river water system are no longer needed to support current missions and therefore provide an opportunity for operating cost reduction. If SRS determines that L-Lake, Par Pond, and the river water system are no longer needed to support future missions and are considered surplus, appropriate NEPA documentation will be prepared.

\subsection{Background}

Par Pond and L-Lake are man-made cooling water reservoirs created in 1958 and 1984, respectively. Par Pond was used to dissipate heated effluents from both P- and R-nuclear production Reactors and L-Lake was used to dissipate heated effluent from L-Reactor. R-Reactor ceased operation in 1964 and P- and L- Reactors ceased operation in 1988.

\subsubsection{River Water System}

The river water system consists of three pumphouses. Two of the pump houses are located on the Savannah River and one is located at Par Pond. The 5G pumphouse that supports D-Area is not part of this action. All pumphouses are interconnected through approximately 80 kilometers $(\mathrm{km})$ [50 miles (mi)] of underground concrete piping network that supplies cooling water to the $1575 \mathrm{~m}^{3}$ ( 25 million gallon) reservoir in each reactor area. Each pumphouse contains 10 pumps and each pump is rated to deliver more than $1.5 \mathrm{~m}^{3} / \mathrm{sec}\left(53 \mathrm{ft}^{3} / \mathrm{sec}\right)$. 


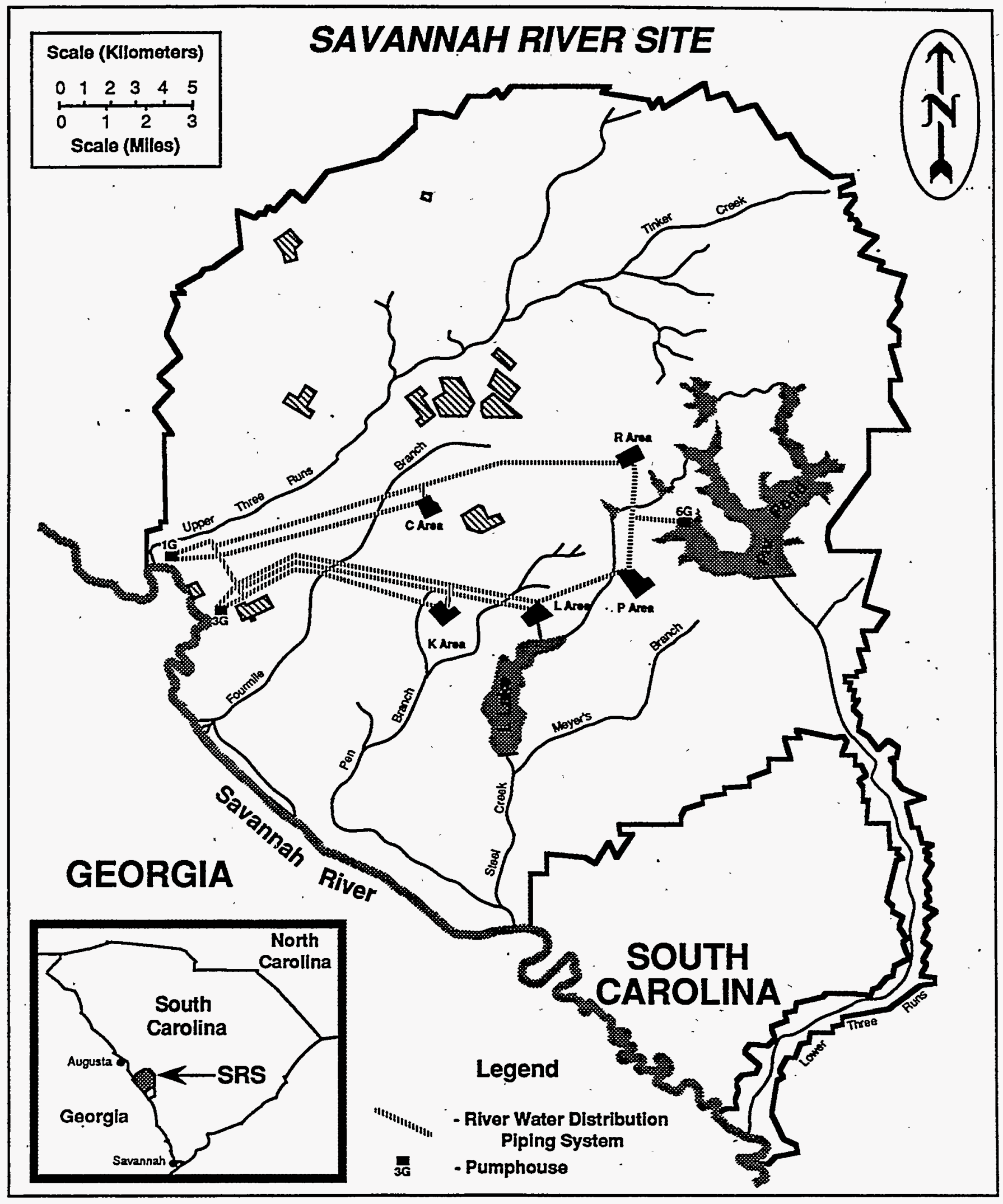

Figure 1. Location of the River Water Distribution Piping System between the 1G, 3G and 6G Pumphouses on the Savannah River, Par Pond and L-Lake at the Savännah River Site, South Carolina. 
Under full flow conditions, approximately $11 \mathrm{~m}^{3} / \mathrm{sec}\left(388 \mathrm{ft}^{3} / \mathrm{sec}\right)$ is supplied to a reactor reservoir from the river during reactor operation. Cooling water is supplied from the reservoir to heat exchangers, coolers, radiators, etc. in the reactor building and is discharged to the outfall canal. Excess water to the reservoir overflows to an overflow line and is conveyed to the outfall canal. Water is returned to the Savannah River via Par Pond and L-Lake in P and L areas, respectively.

Since the shutdown of SRS reactors, tiver water pumpage has been reduced to supply minimum requirements. One of the river water pumphouses and the Par Pond pumphouse are shutdown. The river water system valves into $\mathrm{C}$ and $\mathrm{K}$ areas have been closed except for small area demands which account for approximately 0.06 to $0.12 \mathrm{~m}^{3} / \mathrm{sec}$ ( 2 to $4 \mathrm{ft}^{3} / \mathrm{sec}$ ). The river water system valves into $\mathrm{P}$ and $\mathrm{L}$ areas are adjusted as necessary to maintain flow to Par Pond and L-Lake: Flow to L-Lake is added as necessary to maintain the lake level between $56.7 \mathrm{~m}(189 \mathrm{ft})$ and $57 \mathrm{~m}$ $(190 \mathrm{ft})$ elevation and to maintain required flows in Steel Creek downstream from the reservoir as dictated in the Environmental Impact Statement (EIS) for the operation of L-Reactor (DOE, 1984). Similarly, water has been added to Par Pond to maintain the level at full pool. Downstream flow. requirements in Steel Creek and Lower Three Runs can be adjusted at L-Lake and Par Pond.

Par Pond Dam is an earthen fill embankment that is $20.6 \mathrm{~m}$ (68 ft) high at its maximum crosssection and approximately $1372.5 \mathrm{~m}(4,500) \mathrm{ft}$ long. The spillway structure consists of a rectangular, uncontrolled weir discharging into an $2.4 \times 2.4 \mathrm{~m}$ ( 8 by $8 \mathrm{ft}$ ) vertical shaft that in turn discharges to a $2.4 \times 2.4 \mathrm{~m}(8 \times 8 \mathrm{ft})$ box conduit. The elevation of the weir and the water level at which overflow occurs, is $59.7 \mathrm{~m}(199.2 \mathrm{ft}) \mathrm{msl}$. The 1,000 acre L-Lake was constructed by the U.S. Corps of Engineers by constructing an earthen dam across Steel Creek upstream from the Seaboard Coast Line railroad bridge. This lake is about $1,170 \mathrm{~m}(3,900 \mathrm{ft})$ at its maximum width, with an average width of approximately $600 \mathrm{~m}(2,000 \mathrm{ft})$ and extends $7.2 \mathrm{~km}(4.5 \mathrm{mi})$ upstream from the dam.

\subsubsection{Par Pond}

Par Pond is a 2,640 acre recirculating cooling water reservoir created in 1958 by the construction of an earthen dam on Lower Three Runs (Figure 2). Par Pond discharges into Lower Three Runs, which discharges into the Savannah River approximately $32 \mathrm{~km}(20 \mathrm{mi})$ downstream. Releases from R-Reactor in the form of process leaks, purges, and makeup cooling water have contaminated Par Pond with low levels of radioactive materials, primarily Cesium-137 (Cs-137) (originally 222 curies in Par Pond, R-Reactor canals, and Lower Three Runs). All radioactive isotope releases except tritium ceased following the shutdown of R Reactor in 1964. Most of the Cs-137 resides in the upper $0.3 \mathrm{~m}(1 \mathrm{ft})$ of fine sediments and is found associated with the original stream corridors. Since the half-life of Cs-137 is 30 years, more than half of the Cs-137 associated with Par Pond has decayed since releases occurred [currently about 43 curies remain in Par Pond itself, over twothirds occur below the $57 \mathrm{~m}(190 \mathrm{ft})$ level]. Elevated levels of mercury have also accumulated in sediments from pumping water from the Savannah River (DuPont, 1987).

During a March 1991 inspection of Par Pond dam, a small depression was noted on the downstream slope. DOE ordered a structural investigation into the cause of the depression and simultaneously initiated a precautionary drawdown of the reservoir. From June through September 1991, Par Pond was lowered about $5.7 \mathrm{~m}$ (19 ft) from $60 \mathrm{~m}$ to $54.3 \mathrm{~m}$ [nominal 200 to $181 \mathrm{ft}$ (msl)] elevation, approximately two-thirds of its original volume. A level below $55 \mathrm{~m}$ (182 $\mathrm{ft}$ ) was chosen in order to reduce the risk and consequences of potential flooding to downstream communities in the unlikely event of dam failure. The drawdown exposed about 1,340 acres of sediment over $53 \mathrm{~km}$ (33 mi) of shoreline (Figure 2) (Marcy et al., 1994). 


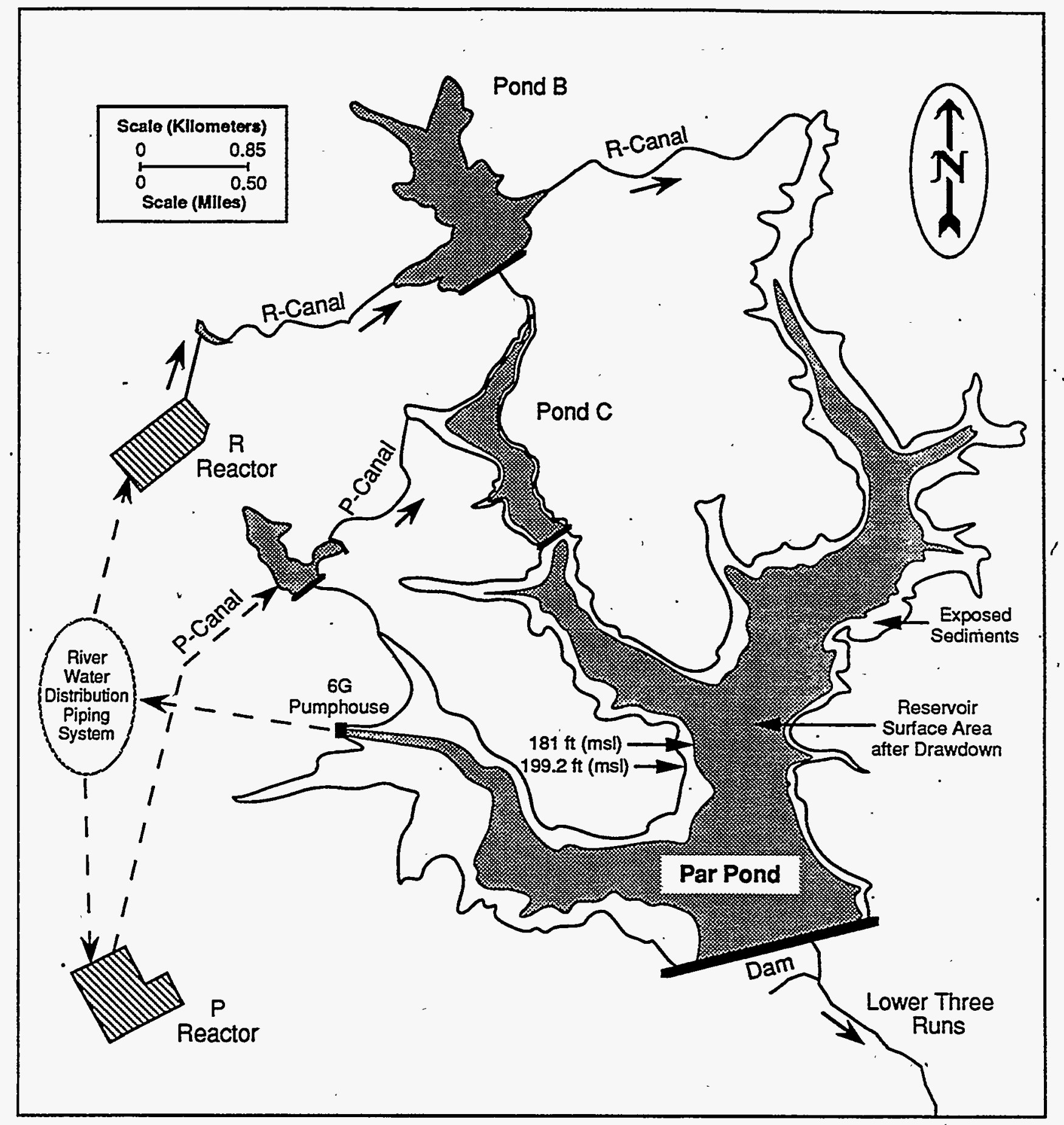

Figure 2. Exposed sediment areas in Par Pond at the $54 \mathrm{~m}(181 \mathrm{ft})$ level and the P- and RReactor water distribution system. 


\section{Regulatory Issues}

It is essential to understand the impacts of the drawdown on the reservoir and regulatory issues in order to evaluate the potential impacts of the proposed action and alternatives. DOE prepared a unique National Environmental Policy Act (NEPA) document in July 1991 called a Special Environmental Analysis (SEA) (DOE, 1992) after consultation with the Council on Environmental Quality (CEQ) regarding "alternative arrangements pursuant to Section 1506.11 of the CEQ regulations for implementing NEPA 940 CFR 1506." The document covered an emergency action and assessed the environmental impacts on the aquatic and terrestrial ecosystem during drawdown, dam repair, and refill to full pool $60 \mathrm{~m}+/-0.3 \mathrm{~m}(200 \mathrm{ft}+/-1 \mathrm{ft})$. The environmental consequences of the proposed action of fluctuating water levels in Par Pond was to be evaluated in a NEPA document as discussed in the Par Pond Comprehensive Environmental Response, Compensation, and Liability Act (CERCLA) Interim Action Proposed Plan (IAPP).

The Par Pond operable unit, consisting of the Par Pond reservoir, the series of pre-cooler ponds and canals, and Lower Three Runs, is listed as a CERCLA unit in Appendix C of the Federal Facility Agreement (FFA). At the time of drawdown, SRS notified the Environmental Protection Agency (EPA-Region IV) and South Carolina Department of Health and Environmental Control (SCDHEC) that possible dam failure at Par Pond could be an imminent and substantial danger to public health, safety, and the environment under CERCLA. DOE and EPA viewed the Par Pond drawdown as a removal action under Section 106 of CERCLA. Consequently, an Interim Action Proposed Plan (LAPP) was prepared to address mitigation of risks associated with the exposed sediments.

Under CERCLA, remedial alternatives were developed for interim remediation of the exposed sediments caused by the reservoir drawdown. The alternatives developed were based on limited existing information regarding the physical and chemical characteristics of the sediments of $\mathrm{Par}$ Pond and hazardous substances within these sediments. DOE is conducting ongoing investigations of the Par Pond CERCLA unit. Regarding the remediation/restoration of Par Pond, DOE scoped a phased approach to identify the optimal sequence of investigative activities and unit actions. An interim action was proposed to remediate the immediate potential risks from exposed sediments. An Investigation and potential remediation is planned under CERCLA and will be scheduled consistent with the FFA.

The preferred interim alternative, sent for public comment, consisted of refilling and maintaining Par Pond at the original $60 \mathrm{~m}+/-0.3 \mathrm{~m}(200+/-1 \mathrm{ft})$ level following the repair of the Par Pond dam. Based on public comments to the IAPP, the preferred alternative was modified to include maintenance of the reservoir at the $60 \mathrm{~m} \mathrm{t/-0.3} \mathrm{m}(200 \mathrm{ft}+/-1 \mathrm{ft})$ water level until a NEPA evaluation could be prepared. This NEPA document would evaluate the environmental impacts from reduced flow to Lower Three Runs and fluctuating reservoir water level.

The CERCLA interim action provided the most timely reduction of risk to human health and the environment through submergence of the sediments with a layer of water upon restoration of the $\mathrm{Par}$ Pond water level. The water layer attenuates gamma radiation emitted from the decay of $\mathrm{Cs}$ 137 and minimizes the potential for sediments to become airborne. The interim action also allowed a gradual recovery of the reservoir to essentially pre-drawdown ecological conditions. 


\section{Environmental Impacts of Drawdown}

Two operational features separate Par Pond from other regional reservoirs. First, no public access is permitted. This significantly reduces two common types of environmental impacts on public waters: - nonpoint runoff from large-scale industrial or agricultural regions and fish mortality caused by commercial or sport fishing. Second, for the past three decades, the water level in Par Pond was maintained at nominal $60 \mathrm{~m}(200 \mathrm{ft})$ by addition of water from the Savannah River, permitting the development of an especially productive and diversified littoral zone. River water also added nitrogen and phosphorus that effectively fertilized the lake. Moderate nutrient enrichment and hydrologic stability resulted in the development of a rich and diversified ecosystem. Although Par Pond is man-made, it has a unique ecology and is known worldwide through more than 250 scientific publications and 25 Masters and Doctoral theses (Marcy et al., 1994).

Drawdown of Par Pond had three major repercussions: reduced surface area and water volume, eliminated the littoral zone and its interrelated communities, and exposed contaminated sediments. Before the 1991 drawdown, much of the shoreline was characterized by beds of persistent (primarily cattails, Typha spp.) and nonpersistant (primarily waterlilies, Nymphaea odorata) aquatic macrophytes. These beds varied from 19.5 to $39 \mathrm{~m} \mathrm{(65} \mathrm{to} 130 \mathrm{ft})$ in width. An analysis of remote sensing data from 1988 and 1989 indicates that from 445 to 470 acres of cattails and 310 to 370 acres of waterlilies were present along Par Pond's shoreline on approximately 30 to 35 percent of the lake surface area (Jensen et al., 1991, $1993 \mathrm{a}, \mathrm{b}$ ). These surface macrophytes, along with beds of submergent macrophytes, provided excellent habitat for littoral zooplankton, fishes, reptiles, mammals, and waterfowl. The Par Pond littoral zone was especially well developed when compared to most southeastern impoundments because of the stable water elevation from 1958 to 1991 (Wilde, 1985; Bowers, 1992). The drawdown removed approximately 50 percent of the lake's surface area, most of which was valuable littoral habitat. This littoral community was an important foraging resource for reptiles, waterfowl, shore birds, and mammals.

These transitory losses can best be described by changes in the functionality of the community where macrophytes, cattails, waterlily, and water lotus (Nelumbo lutea) dominate. Their loss initially destabilized the shoreline. After heavy rainstorm events, major erosion perpendicular to the shoreline was observed. By the fall of 1992, about 1 year after drawdown, macrophyte growth had again covered much of the new smaller littoral zone. Macrophytes had recolonized the new littoral zone at the $54 \mathrm{~m}(181 \mathrm{ft})$ level. However, detailed studies have not been performed to quantify the nature of these changes.

These habitat changes brought further changes to other components of the lake's communities. During the loss of the littoral zone, a large proportion of the invertebrate benthic community perished, particularly mussels and clams that could not escape downslope into the receding water (SREL, 1991; Whicker, 1991a, DOE, 1993). Macrophytes, Eurasian water-milfoil (Myriophyllum spicatum), waterlily, and cattail recolonized this zone especially in protected cove areas of the shoreline (Whicker, 1991a).

Fish populations in Par Pond are similar to other southeastern reservoirs in terms of diversity (Wilde, 1985). During the first months after the Par Pond drawdown, predation from largemouth bass (Micropterus salmoides),(some exceeding 6.8 kilograms $(\mathrm{kg})$ or $15 \mathrm{lbs}$ ), bluegill (Lepomis macrophirus), and pickerel (Esox spp.,) significantly depleted small baitfish in the exposed, newly created littoral zone with little macrophyte cover (Whicker et al., $1993 \mathrm{a}, \mathrm{b}$ ). There was a less extensive mortality of medium-sized fish, but not to the degree of the smaller fish. The immediate loss of nursery and permanent habitats for nearshore, smaller species reduced the total fish population in Par Pond during 1991 and 1992. However, some recruitment was observed during 
1992, possibly caused by macrophyte recovery in some areas of the basin. Monthly condition factors (robustness) for largemouth bass, the dominant predator, were significantly reduced and appeared to follow prey availability on a seasonal frequency (Whicker et al., $1993 \mathrm{a}, \mathrm{b}$ ).

The lake and surrounding environs support a variety of vertebrates including the American alligator (Alligator mississippiensis), large populations of migrating waterfowl, white-tailed deer (Odocoileus virginianus), wild pigs (Sus scrofa), and the federally protected bald eagle (Haliaeetus leucocephalus). Based on limited field surveys, lower water levels did not significantly affect the alligator populations in $\mathrm{Par}$ Pond (DOE, 1993). However, movements of the alligators suggested that the drawdown had a marked and disruptive effect on their normal spatial distribution and movement patterns. The most important effect of the drawdown was a reduction in nesting habitat and protective cover for juveniles (Brisbin et al., 1992).

Waterfowl habitats decreased after the drawdown. Par Pond had one of the largest inland overwintering diving duck populations in South Carolina. Surveys of the Par Pond ecosystem in the 1991-1992 winter revealed that overwintering numbers of waterfowl were reduced after the drawdown. In contrast to this, waterfowl numbers observed on other nearby impoundments were higher than those documented prior to the drawdown. Overwintering numbers increased during the winter of 1992-1993, but still were less than those prior to 1991.

Records of bald eagles on Par Pond date back to 1959. Despite the drawdown, censuses have documented the continued presence of this species near Par Pond, with most observations during the fall and winter months (DOE, 1992). The existing bald eagle nest site near Par Pond was active following the drawdown, with two fledglings produced in 1993 (DOE, 1993).

The exposed sediments provided habitats for a mixture of wetland and old-field flora dominated by bog rushes (Juncus spp.), maidencane (Panicum hemitomon), bulrush (Scirpus cyperinus), dog fennel (Eupatorium spp.) and sedges (Cyperus spp.) (Whicker, 1991a). This invading flora created a new habitat for mammalian species common to the Par Pond environs and a food web pathway for the Cs-137 and mercury to terrestrial and wetland herbivores.

Resident populations of both white-tailed deer and wild pig are controlled through public hunts performed each fall at SRS. Following the drawdown, both species began to forage extensively on the plants colonizing the exposed lakebed (WSRC, 1992). However, the monitoring of animals harvested during the fall hunts revealed that radionuclide tissue burdens posed no threat for human consumption (DOE, 1993).

\section{Human Health Risks}

A. limited baseline risk assessment based on existing data only was conducted at the request of EPA - Region IV to evaluate potential human health risks of exposure to Par Pond sediments (WSRC, 1992). Potential carcinogenic effects were characterized by estimating from projected intake and chemical-specific dose-response data the probability that an individual would develop cancer in excess of the general population over a lifetime. Potential noncarcinogenic effects were characterized by comparing projected intakes of contaminants with acceptable daily intakes or reference doses (RFD). Risk data were compiled and presented in a baseline risk assessment using existing data for Par Pond (WSRC, 1992).

To interpret the risk characterization results, a risk of less than one excess cancer in one million people $\left(1 \times 10^{-6}\right)$ is considered normal background and acceptable by EPA. The EPA target risk range is from one in ten thousand $\left(1 \times 10^{-4}\right)$ to $\left(1 \times 10^{-6}\right)$. Risks falling within this range may 
require an evaluation of remedial actions to determine if risks can be reduced below the $1 \times 10^{-6}$. Risks greater than $1 \times 10^{-4}$ (default values) generally warrant remedial action.

Data used in the baseline risk assessment were obtained from previous studies and existing sampling programs performed at Par Pond. The Chemicals of Potential Concern (COPCs) included barium, beryllium, cadmium, chromium, mercury, Cs-137, strontium-90, cobalt-60, plutonium-238, and plutonium-239. Based on the results of the risk assessment, Cs-137 accounted for the majority of the carcinogenic risk from the exposure pathways identified. Of the scenarios evaluated for noncarcinogenic effects, mercury was the primary contaminant responsible for the projected adverse effects (WSRC, 1992).

For the exposure condition scenarios, worker on unit, unit-specific, realistic intake parameters to estimate exposure were developed instead of using EPA default values. However, for future exposure condition scenarios, EPA default values were used (WSRC, 1992).

Carcinogenic risks calculated for the current land use scenario indicate only one pathway, external exposure from sediment to the Par Pond unit worker, exceeds the EPA-established target risk of 1 $x$ 10-6; the risk for this pathway is calculated to be $4 \times 10^{-5}$, within the EPA target risk range. By managing work conditions and duration, this risk can be minimized.

According to the baseline risk assessment, scenarious that also exceeded the EPA target risk range included the risk to the future Par Pond unit worker from external exposure $\left(10^{-3}\right)$ and the risk to the future on Par Pond unit resident from external exposure to the sediment, $\left(10^{-2}\right)$. Concern for potential noncarcinogenic effects was indicated for the ingestion of fish by the future on Par Pond unit resident. The potential carcinogenic risks calculated for the hypothetical future Par Pond unit worker and future Par Pond unit resident exposed to Par Pond sediments were based on very conservative assumptions and represent the worst case scenario. Because of the limited availability of data, only the most conservative assumptions were used. All the EPA default values and only the maximum contaminant concentrations detected were used in the calculations.

After submitting the draft risk assessment, EPA requested SRS to submit an IAPP (WSRC, 1994) describing the potential remedial actions to mitigate exposure to the sediments. The purpose of the IAPP was to recommend an interim measure to mitigate risks associated with Cs-137 in the exposed sediments and impacts to the ecosystem as a result of the drawdown. The approach included consideration of the complexity of the ecosystem, the large size of Par Pond, the large volume of contaminated sediments, and the current institutional controls existing at SRS. There were approximately 1340 acres of exposed sediment as a result to the drawdown of Par Pond. The volume of sediment potentially requiring remediation was estimated at about 1.68 million cubic meters ( 2.2 million cubic yards).

Based on the analysis of alternatives, refilling and maintaining the pond at full pool was selected as the preferred interim action. Refilling Par Pond provided the most timely reduction in the risk to human health and the environment through submergence of the exposed sediments with a layer of water. The water layer precluded sediments from becoming airborne and attenuate most of the gamma radiation emitted from the decay of Cs-137 and also allowed for gradual recovery of the ecosystem to its original pre-drawdown condition (WSRC, 1995). Airborne release of Cs-137 from the sediments did not exceed the National Emission Standards for Hazardous Air Pollutants (NESHAP) standard after close monitoring during drawdown (Marter and Boni, 1991).

Many of the public comments received at the public meeting in December 1994 on the CERCLA IAPP suggested that SRS should reduce costs by not maintaining the pond at full pool but rather let it fluctuate naturally (WSRC, 1995). Discontinuing the practice of pumping river water from the 
Savannah River to keep both cooling water reservoirs at full pool to support nuclear material production represents a saving to the Site of about 2 million dollars annually (Hammond, 1994).

Historically, water releases from Par Pond have occurred over a fixed weir at the Par Pond dam. The elevation of this weir has been resurveyed recently and determined to be approximately $59.7 \mathrm{~m}$ (199.2 $\mathrm{ft}-\mathrm{msl}$ ) elevation. Modeling and analytical work to date, including the period of drawdown, have been based on a nominal full-pool elevation of $60 \mathrm{~m}(200 \mathrm{ft}-\mathrm{msl})$ and estimates of exposed acreage have been subsequently adjusted to reflect a discharge weir elevation and full pool of approximately $59.7 \mathrm{~m}$ (199.2 ft-msl). Consequently, exposed sediment acreage estimates are considered to be reasonable approximations of the true values and therefore the $59.7 \mathrm{~m}(199.2 \mathrm{ft}$ $\mathrm{msl}$ ) elevation is used in this document.

\subsubsection{L-LAKE}

L-Lake (Figure 3) was constructed by DOE in 1984 as a cooling water reservoir to dissipate the thermaI effluent discharged from the operation of L-Reactor (DOE, 1984). Cooling water, discharges were managed by varying reactor power levels to maintain a balanced biological community in the lake [i.e., about 50 percent of the lake would not exceed $90^{\circ} \mathrm{F}\left(32.2^{\circ} \mathrm{C}\right)$ according to State of South Carolina Class B water quality standards (Regulation 61-68)]. The lake inundated about 225 acres of wetlands and 775 acres of uplands in the Steel Creek corridor. The normal pool elevation of the lake is maintained between $56.7 \mathrm{~m}(189 \mathrm{ft})$ and $57 \mathrm{~m}(190 \mathrm{ft})$ above mean sea level (msl), the top of the dam being about $60 \mathrm{~m}(200 \mathrm{ft})$ above mean sea level. L=Lake is a productive reservoir and the ecology and water quality has been extensively monitored both during and after the input of thermal effluent from 1985-1987. Gladden et al. (1988) and Wike et al. (1994) provide the most comprehensive summaries of the data collected on the water chemistry and ecology of L-Lake.

\subsubsection{Flows in Steel Creek below L-Lake Dam}

In 1954 Steel Creek (Figure 3) began receiving thermal effluents from P- and L-Reactors. By 1961 a total of $24 \mathrm{~m}^{3} / \mathrm{sec}\left(850 \mathrm{ft}^{3} / \mathrm{sec}\right)$ of thermal effluent was being released by both reactors into Steel Creek. From 1961 to 1964 P-Reactor partially used the Par Pond recirculating system. In 1964 all P-Reactor effluent was diverted to Par Pond, and in 1968 L-Reactor was put on standby. In 1981, DOE initiated activities to restart L-Reactor. Based on an environmental assessment of various thermal mitigation alternatives, L-Lake was constructed in 1984 along the upper reaches of Steel Creek to receive and cool the heated effluents from L-Reactor prior to their release into Steel Creek.

Supplemental flow is maintained through the L-area to maintain the level of L-Lake and the minimum regulatory required flows in Steel Creek. During preparation of the L-Reactor EIS (DOE, 1984) concerns were raised that a sudden cessation of cooling water flow would strand aquatic organisms and create adverse impacts on the aquatic community. Minimum flows of approximately $1.5 \mathrm{~m}^{3} / \mathrm{sec}\left(53 \mathrm{ft}^{3} / \mathrm{sec}\right)$ year-round and $3.0 \mathrm{~m}^{3} / \mathrm{sec}\left(106 \mathrm{ft}^{3} / \mathrm{sec}\right)$ during the fish spawning season were established in the EIS to protect the aquatic community in the event of precipitous drops in stream flow rates. The necessity to continue to maintain a $3.0 \mathrm{~m}^{3} / \mathrm{sec}(106$ $\mathrm{ft}^{3} / \mathrm{sec}$ ) spawning flow in Steel Creek was curtailed in 1994 due to minimal impact (Wright, 1994).

Two points are particularly important for this overall consideration. First, the reference flow conditions to which these flow requirements apply are the full reactor cooling flow of $10-11 \mathrm{~m}^{3} / \mathrm{sec}$ (353-388 $\left.\mathrm{ft}^{3} / \mathrm{sec}\right)$, rather than the historical average flow of approximately $1 \mathrm{~m}^{3} / \mathrm{sec}\left(35 \mathrm{ft}^{3} / \mathrm{sec}\right)$. Second, the average annual flow of Steel Creek was determined at a location downstream from SRS Road A, downstream from the confluence of Steel Creek and Meyers Branch. Above the 


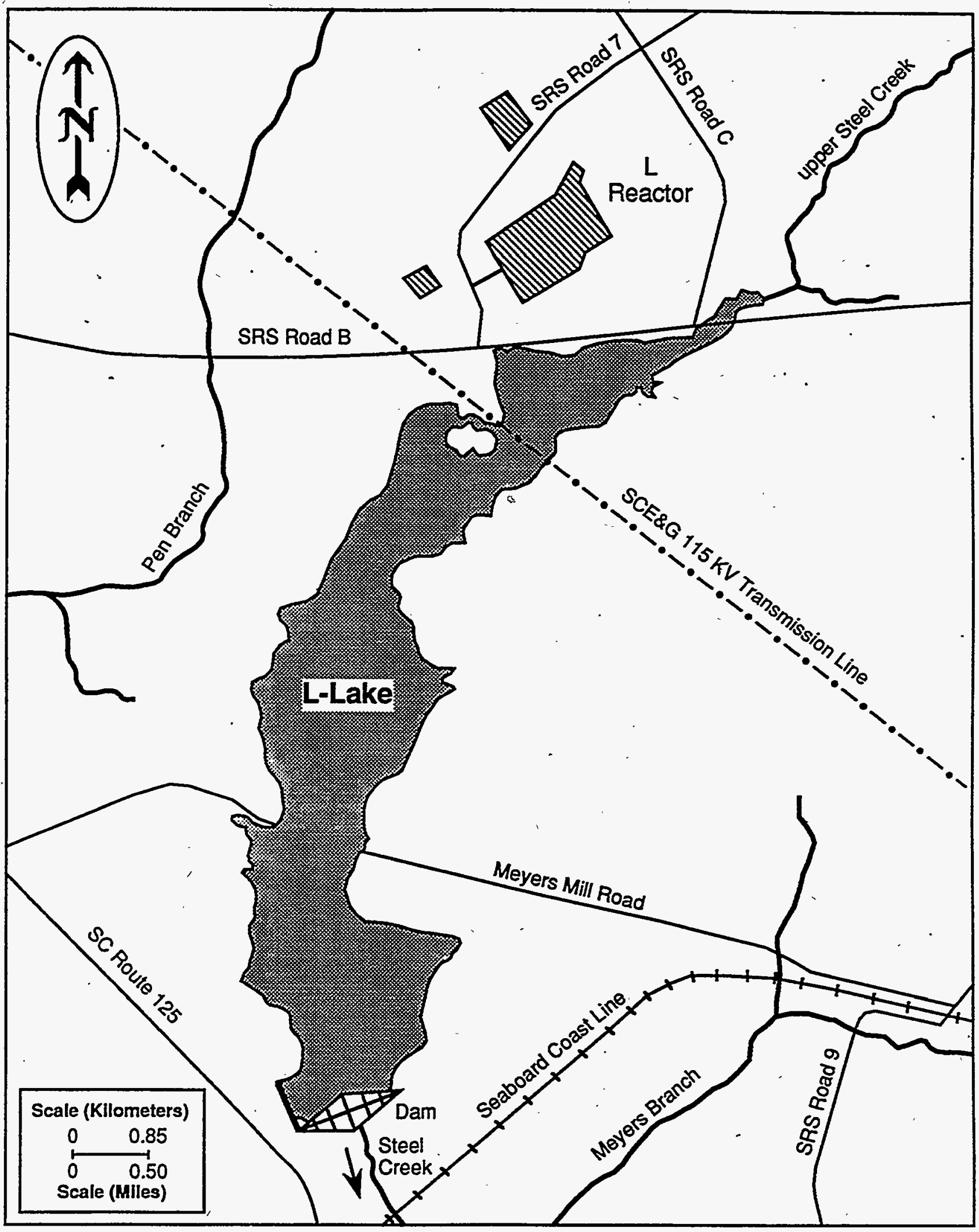

Figure 3. Map of L-Lake and Steel Creek. 
point of confluence, the watershed area of Meyers Branch-is somewhat larger that the watershed of Steel Creek (Moore-Shedrow, 1992).

\subsection{PROPOSED ACTION AND ALTERNATIVES}

\subsection{Proposed Action}

The purpose of the proposed action is to begin an examination of the need for the Site's river water system by (1) developing data needed to evaluate the potential environmental impacts of further reducing or eliminating the flow demands from the Site's river water system in the future and; (2) evaluating the potential of reducing operating costs by allowing the water level in Par Pond to fluctuate naturally through reduced pumping. This action also includes reducing the current flow rates from L-Lake to Steel Creek to natural stream flows while maintaining full pool. Should any of the parameters sampled (e.g., water quality, biota, etc.) exceed established threshold levels during the implementation of the proposed action, water would again be pumped into the reservoir to minimize any impacts by bringing the water level back to an appropriate level.

The electrical cost of pumping from the Savannah River to maintain Par Pond and L-Lake at full pool level and to maintain a $1.5 \mathrm{~m}^{3} / \mathrm{sec}\left(53 \mathrm{ft}^{3} / \mathrm{sec}\right)$ discharge below the dam to Steel Creek from LLake is about $\$ 930,000$ annually $[\$ 360,000$ to maintain Par Pond at full pool and $\$ 570,000$ to maintain a $1.5 \mathrm{~m}^{3} / \mathrm{sec}\left(53 \mathrm{ft}^{3} / \mathrm{sec}\right)$ discharge to Steel Creek from L-Lake]. Costs represent the electrical cost associated with operation of an additional pump over base operation $1 / 4$ to $1 / 2$ time for maintaining the level of Par Pond and an additional pump 40 percent of the time to maintain a continuous discharge of $1.5 \mathrm{~m}^{3} \mathrm{sec}\left(53 \mathrm{ft}^{3} / \mathrm{sec}\right)$ in Steel Creek.

\subsubsection{Par Pond}

Part of the proposed action is to allow the water level in Par Pond to fluctuate naturally from its current actual full pool level of $59.7 \mathrm{~m}$ (199.2 ft). The cessation of river water inputs to the reservoir would result in fluctuations in water level as a result of seasonal and annual variations in rainfall/runoff and evaporation from the reservoir surface (Figure 4). Consequently, different acreages of Par Pond sediments would be exposed at different times. Based on ten years of rainfall data, the expected changes in water elevations in Par Pond were estimated by simulation (USCOE, 1994). Based on topography, aerial photography, best engineering judgment, and ease of calculation, full pool of $60 \mathrm{~m}(200 \mathrm{ft}) \mathrm{msl}$ [actual $59.7 \mathrm{~m}(199.2 \mathrm{ft}-\mathrm{msl})$ ]was selected for the simulation. The simulated model indicates that the water level would not be expected to decline below $58.8 \mathrm{~m}$ (196.2 ft). However, $58.5 \mathrm{~m}$ (195 ft) was choosen as the lower limit for bounding the assessment of the potential environmental impacts of the natural fluctuation of the water level.

It is considered likely that Par Pond sediments at elevations higher than the discharge weir are contaminated to some extent. During at least one of the radionuclide release periods (1963-64), large volumes of water accompanied the release. Consequently, the Par Pond water level may have been up to $.18 \mathrm{~m}(0.5 \mathrm{ft})$ higher than the discharge weir elevation. Although the actual water levels in the reservoir during this period are not known, an upper bound of $.18 \mathrm{~m}(0.5 \mathrm{ft})$ above the weir elevation is considered to be the probable upper limit of sediment contamination; this assumption is reflected in Figure 5. Figure 5 presents the estimated acres of exposed sediment and frequency of submergence for predicted (modeled) and actual fluctuating water levels in Par Pond based on the simulated data. The modeling assumes $0.28 \mathrm{~m}^{3} / \mathrm{sec}\left(10 \mathrm{ft}^{3} / \mathrm{sec}\right)$ is released from the reservoir to maintain flows in Lower Three Runs. 


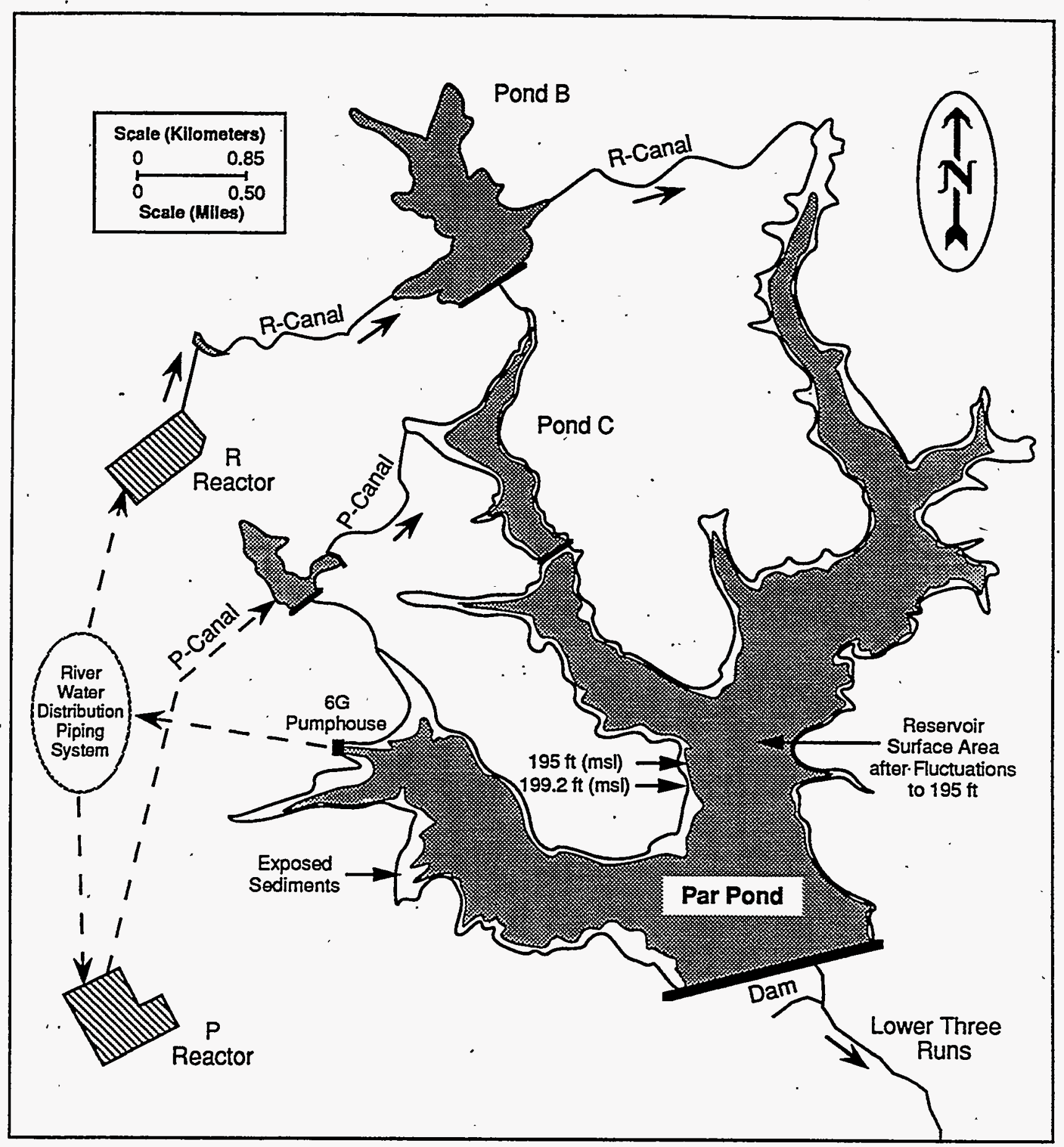

Figure 4. Exposed sediment areas in Par Pond at the $58.2 \mathrm{~m}$ (195 ft) level and the P- and RReactor water distribution system. 


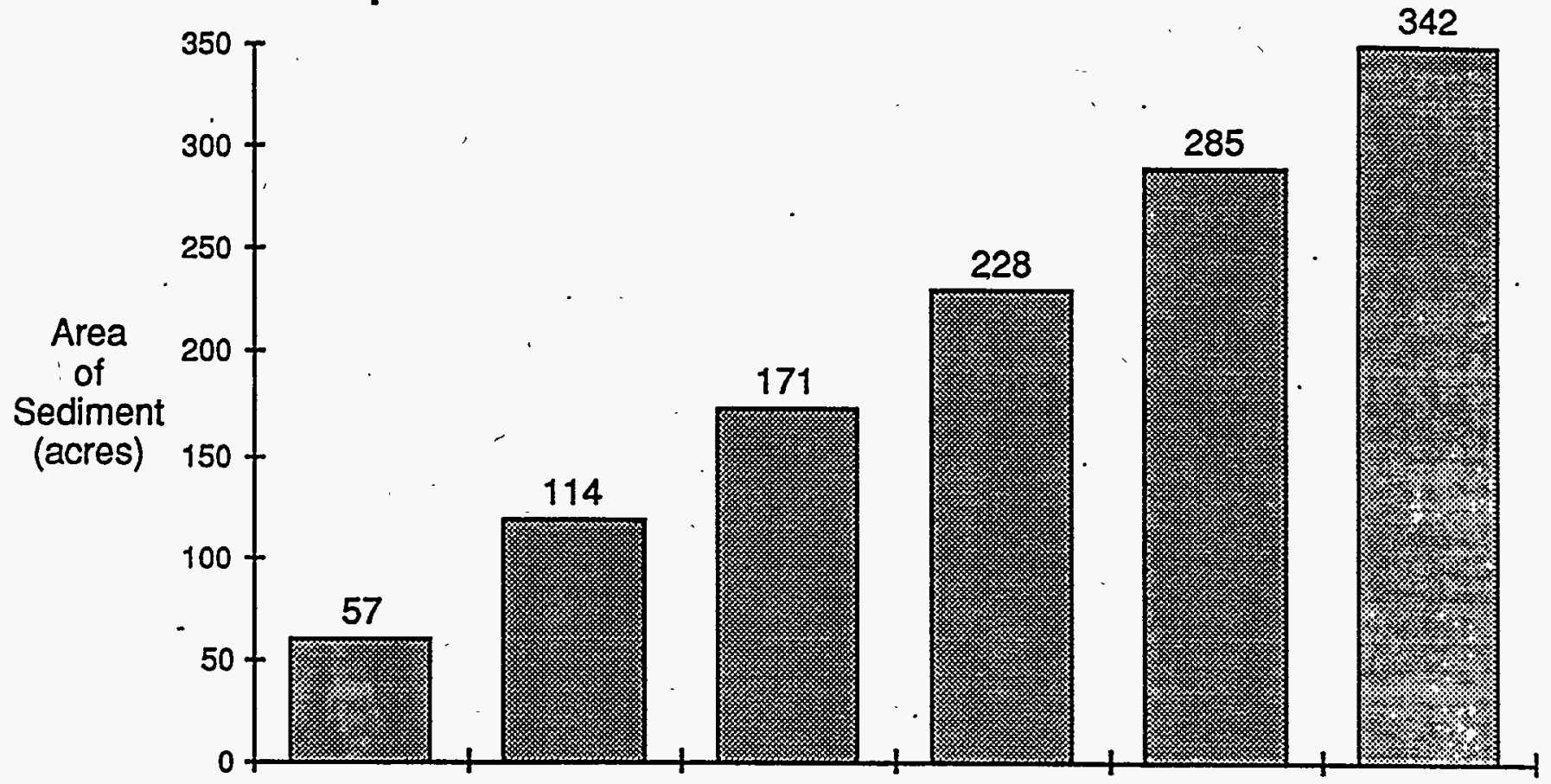

Frequency of Submergence

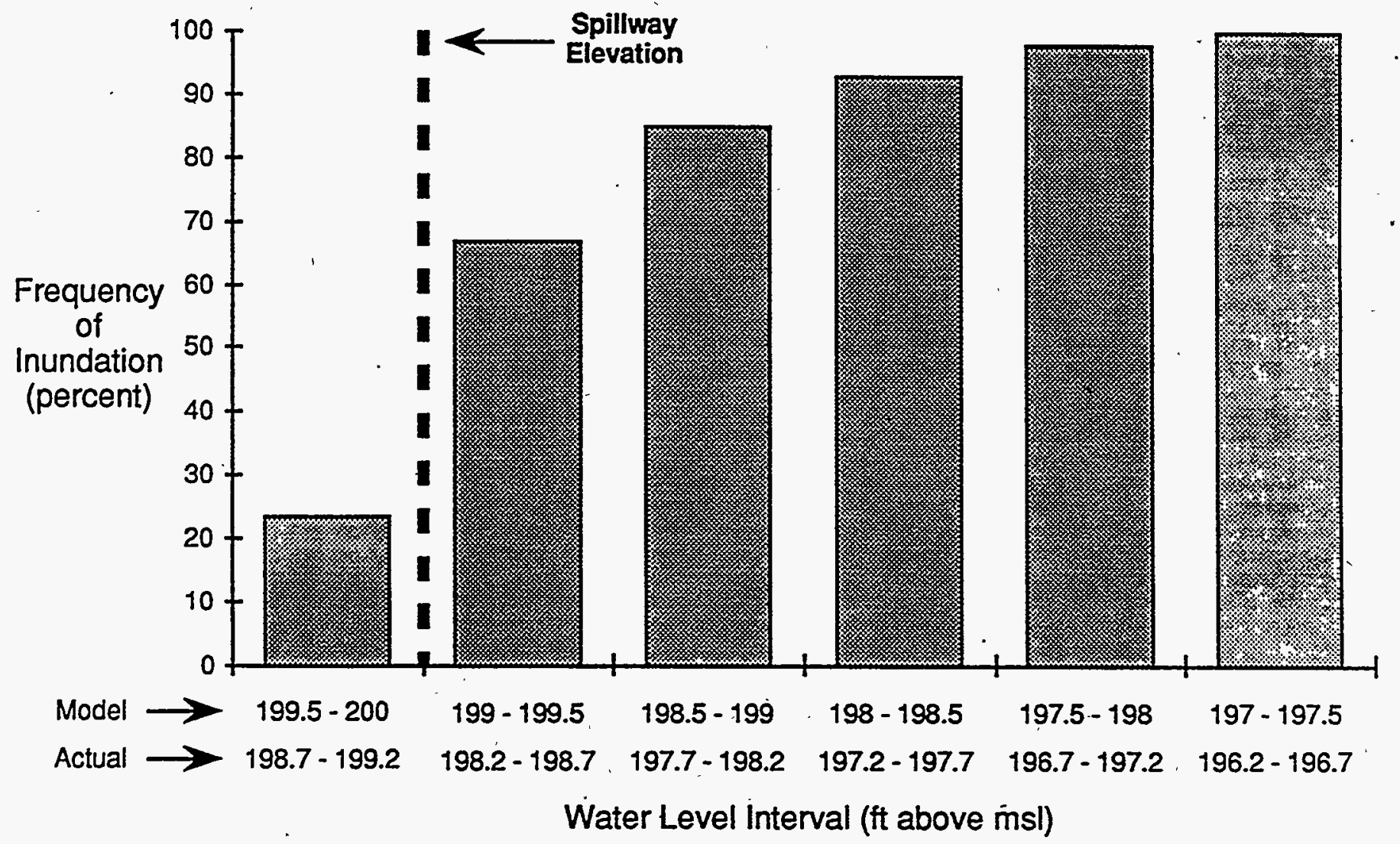

Figure 5. Estimated acres of exposed sediment and frequency of submergence for predicted (i.e., modeled) and actual fluctuating water levels in Par Pond (Based on USCOE, 1994). 
Based on the simulated model (USCOE, 1994), the water level is not expected to decline below approximately $58.8 \mathrm{~m}$ (196.2 ft) [58.5 m (195 ft) as the lower bounding limit] and would remain above $59.4 \mathrm{~m}$ (198.2 ft) over 65 percent of the time if the water flow out of $\mathrm{Par}$ Pond were reduced and maintained at about $0.28 \mathrm{~m}^{3} / \mathrm{sec}\left(10 \mathrm{ft}^{3} / \mathrm{sec}\right)$ in Lower Three Runs (Figure 5). This minimum flow is based on discharge/habitat relationships predicted by an instream flow model and information on fish assemblage structure (del Carmen and Paller, 1993). Flow will be regulated to maintain $0.28\left(10 \mathrm{ft}^{3} / \mathrm{sec}\right)$. Ceasing pumping to Par Pond and allowing the water level to fluctuate would eliminate some of the electrical costs associated with pumping to maintain the reservoir level with a corresponding cost savings of about $\$ 360,000$ annually.

\subsubsection{L-Lake (Steel Creek Flows)}

A watershed hydraulic model was used in conjunction with habitat assessment methodologies to assess whether flows in Steel Creek dictated by both the L-Reactor EIS (DOE, 1984) and the Reactor Operations EIS (DOE, 1990) could be reduced to base flows for pre-L-Lake conditions while maintaining conditions suitable for sustainment of a balanced biological community in Steel Creek. L-Lake's level would be maintained at full pool and the flow from L-Lake would be reduced to base flows of about $0.28 \mathrm{~m}^{3} / \mathrm{sec}\left(10 \mathrm{ft}^{3} / \mathrm{sec}\right)$. The number of river cooling water pumps operated to maintain L-Lake at full pool would be reduced to one pump with a second pump running at 40 percent by this action. This reduction of 0.4 pump would result in a net annual savings of about $\$ 570,000$ (Bryant, 1995).

\subsection{Alternatives to the Proposed Action}

In accordance with NEPA regulations, DOE examined the following alternatives to the proposed action:

- No action, continue present role of the river water system by pumping to Par Pond to maintain full pool at $59.7 \mathrm{~m}+/-0.3 \mathrm{~m}(199.2 \mathrm{ft}+/-1 \mathrm{ft}) \mathrm{msl}$. Maintain a minimum flow of $0.28 \mathrm{~m}^{3} / \mathrm{sec}\left(10 \mathrm{ft}^{3} / \mathrm{sec}\right)$ in Lower Three Runs and continue to pump to L-Lake to maintain full pool and $1.5 \mathrm{~m}^{3} / \mathrm{sec}\left(53 \mathrm{ft}^{3} / \mathrm{sec}\right)$ to Steel Creek at Road A below the dam.

- $\quad$ Reduce pumping to Par Pond and allow levels to fluctuate naturally from full pool $59.7 \mathrm{~m}+/-0.3 \mathrm{~m}(199.2 \mathrm{ft}+/-1 \mathrm{ft})$ and maintain $0.28 \mathrm{~m}^{3} / \mathrm{sec}\left(10 \mathrm{ft}^{3} / \mathrm{sec}\right)$ flow in Lower Three Runs. Continue to pump to L-Lake and maintain a full pool and 1.5 $\mathrm{m}^{3} \mathrm{sec}\left(53 \mathrm{ft}^{3} / \mathrm{sec}\right)$ to Steel Creek.

- $\quad$ Continue pumping to Par Pond to maintain level at $59.7 \mathrm{~m}+/-0.3 \mathrm{~m}(199.2 \mathrm{ft}+/-1$ $\mathrm{ft}$ ) and maintain the minimum flow of $0.28 \mathrm{~m}^{3} / \mathrm{sec}\left(10 \mathrm{ft}^{3} / \mathrm{sec}\right)$ to Lower Three Runs. Maintain L-Lake level but reduce pumping by lowering flows below the dam to Steel Creek from $1.5 \mathrm{~m}^{3} / \mathrm{sec}\left(53 \mathrm{ft}^{3} / \mathrm{sec}\right)$ to base flow conditions of 0.28 $\mathrm{m}^{3} / \mathrm{sec}\left(10 \mathrm{ft}^{3} / \mathrm{sec}\right)$.

\subsubsection{No Action}

One alternative to this proposed action is to take no action. This would consist of continuing to pump water from the Savannah River to Par Pond at the annual electrical cost of about $\$ 360,000$ to keep the reservoir level at full pool. This water level would shield all the Cs-137 in the lake sediments thus eliminating any potential risks from exposed sediments and would allow the continued recovery of the ecosystem. No action would also include continuing to pump river water to L-Lake and maintain $1.5 \mathrm{ft}^{3} / \mathrm{sec}\left(53 \mathrm{ft}^{3} / \mathrm{sec}\right)$ flow in Steel Creek at an annual cost of about 
$\$ 570,000$. No action would continue to require an additional pump to maintain full pool at $\mathrm{Par}$ Pond and L-Lake at an estimated cost of about $\$ 930,000$.

\subsubsection{Reduce Pumping to Par Pond and Allow Fluctuating Water Levels and Continue to Maintain a $1.5 \mathrm{~m}^{3} / \mathrm{sec}\left(53 \mathrm{ft}^{3} / \mathrm{sec}\right)$ Flow in Steel Creek below L-Lake}

Another alternative would be to reduce pumping in Par Pond to maintain a water level of between $58.2 \mathrm{~m}(195 \mathrm{ft})$ and $59.7 \mathrm{~m}(199.2 \mathrm{ft})$ while allowing the level to naturally fluctuate. This would save approximately $\$ 360,000$ in annual pumping electrical costs. This alternative would not allow full recovery of the Par Pond ecosystem and would result in a less productive reservoir. Also, it would allow some sediment to be exposed at times. Continuing to pump to maintain $1.5 \mathrm{ft}^{3} / \mathrm{sec}$ $\left(53 \mathrm{ft}^{3} / \mathrm{sec}\right)$ in Steel Creek below the L-Lake Dam would cost about \$570,000 annually in electrical costs.

\subsubsection{Continue Pumping to Par Pond and Reduce Discharge to Steel Creek from L-Lake from $1.5 \mathrm{~m}^{3} / \mathrm{sec}\left(53 \mathrm{ft}^{3} / \mathrm{sec}\right)$ to $0.28 \mathrm{~m}^{3} / \mathrm{sec}\left(10 \mathrm{ft}^{3} / \mathrm{sec}\right)$}

Another alternative would be to continue to pump river water to Par Pond from the Savannah River with electrical costs of $\$ 360,000$ per year. The potential impacts would be the same as for the no action alternative. This alternative would reduce the discharge to Steel Creek from L-Lake from $1.5 \mathrm{~m}^{3} / \mathrm{sec}\left(53 \mathrm{ft}^{3} / \mathrm{sec}\right)$ to $0.28 \mathrm{~m}^{3} / \mathrm{sec}\left(10 \mathrm{ft}^{3} / \mathrm{sec}\right)$, and save about $\$ 570,000$ in pumping electrical costs. This alternative might impact the Steel Creek ecosystem due to the reduced flows.

\subsection{ENVIRONMENTAL CONSEQUENCES OF THE PROPOOSED ACTION AND ALTERNATIVES}

The SRS occupies an area of approximately $800 \mathrm{~km}^{2}\left(310 \mathrm{mi}^{2}\right)$ in southwestern South Carolina (Figure 1). The site borders the Savannah River for about $27 \mathrm{~km}$ (17 mi) near Augusta; Georgia, and Aiken and Barnwell, South Carolina. SRS contains five nuclear production reactor areas, two chemical separation areas, waste processing, storage and disposal facilities, and various supporting facilities. The locations of Par Pond and L-Lake are depicted in Figure 1. The Final Supplemental Environmental Impact Statement for the Defense Waste Processing Facility (DOE, 1994a) and the most recent socioeconomic survey of the six-county SRS area of influence (NUS, 1992) contain additional information on SRS areas and facilities, and the areas surrounding the SRS.

\subsection{Par Pond and Lower Threé Runs}

\subsubsection{Par Pond}

Implementation of the proposed action of allowing the surface water level of Par Pond to fluctuate from a full pool of approximately $59.7 \mathrm{~m}(199.2 \mathrm{ft})$ to $58.2 \mathrm{~m}$ (195 ft) could result in a reduction of the reservoir's predicted (modeled) water level to about $58.8 \mathrm{~m}$ (1.96.2 ft) exposing about 340 acres of sediment [about 500 acres at $58.2 \mathrm{~m}$ (195 ft)] (Figure 5). The level is expected to remain at about $59.7 \mathrm{~m}$ (198.2 ft) for over 65 percent of the time exposing only about 115 acres of sediment. This action is expected to cause some changes in comparison to what had been a hydrologically stable and biologically productive ecosystem over the 33 years when the Par Pond was at full pool before drawdown in 1991. The fluctuating water levels are expected to have three potential impacts on Par Pond: (1) a reduction and instability in the littoral (shore) zone and its interrelated communities; (2) the maximum exposure of up to 340 acres of sediments [about 500 
acres at $58.2 \mathrm{~m}$ (195 ft)] contaminated with Cs-137 and mercury; and (3) loss of nutrients to the reservoir because of reduced pumping from the Savannah River which would lower its productivity and change the species composition and perhaps increase the uptake of Cs-137 in biota. However, over time it is expected that the ecosystem would become similar to most seasonally fluctuating southeastern impoundments.

\section{Littoral Communities}

The first potential impact involves the re-establishment of a new littoral community that would be more characteristic of natural reservoir conditions. Similar littoral communities would become established below the wave zone but are expected to be more unstable and transitory in nature. The Par Pond littoral zone was especially well developed when compared to most southeastern impoundments because of the stable water level from 1958 to 1991 (Wilde, 1985; Bowers, 1992). Boyd (1970) and Marshall and LeRoy (1971) also noted that the littoral community in Par Pond had a somewhat "artificial" productivity compared to other southeastern reservoirs due to water levels remaining relatively stable. They point out that large drawdowns are caused by water consumption in most other reservoirs and do not receive make-up water as is the case for Par Pond. The drawdown removed about 50 percent of the reservoir's surface area, most of which was valuable littoral zone which is important as a foraging resource for reptiles, waterfowl, shore birds, and mammals. The impacts of natural fluctuation would be far less than those due to the drawdown to the $54 \mathrm{~m}(180.2 \mathrm{ft})$ level as about 35 percent of the sediment would be exposed as compared to drawdown. Over time the communities would be similar to most annual fluctuating southeastern impoundments.

Narumalani (1993) estimated the acreage of aquatic vegetation that would develop at various water levels for Par Pond. This analysis required the development of a digital elevation model for the reservoir being derived from existing topographic data and aerial photography of the reservoir at various levels during the drawdown. The acreage of aquatic macrophytes is affected by water levels in Par Pond [i.e., about 800 acres at $59.7 \mathrm{~m}$ (199.2 ft) (full pool) and 600 acres at $58.2 \mathrm{~m}$ $(195 \mathrm{ft})]$. Macrophyte acreage predictions were developed for the stable water level conditions; both the acreage and species composition of the aquatic macrophyte community would be expected to differ depending on whether water levels were stable at the specific level, or fluctuated around this water level as a mean water level. At this range of fluctuation, it is anticipated that a substantial and productive macrophyte community will develop, although the species composition is likely to be somewhat different than that which occurred under the more stable water level regime. However, because of the duration of the recent drawdown, it is expected that the macrophyte community may require several years to return to its earlier configuration (Gladden et al., 1995).

\section{Nutrient Reduction}

The dissolved ion concentrations in Par Pond were historically maintained as a result of a history of recirculation, evaporation, and Savannah River water inputs. The proposed action of reducing the pumping of make-up water from the Savannah River would result in decreasing ions to the Par Pond ecosystem. The conductivity of the surface waters was reduced from about 80-100 umhos $/ \mathrm{cm}$ to 30 umhos/cm during the drawdown. After the drawdown, the relatively large influence of groundwater and natural surface inputs, which were very low in dissolved ions, began to dominate the water chemistry of the basin (Whicker et al., 1993b). As potassium concentrations decrease, organisms take up more Cs-137, which is a potassium analog. Associated with these reduced dissolved ion concentrations, increased levels of Cs-137 have been found in muscle of largemouth bass suggesting increased biological mobility of Cs-137 and possibly other contaminants in the reservoir (Whicker, 1991b; DOE, 1993). It is expected that the refill of Par Pond with Savannah River water resulted.in nutrient influx which may have temporarily offset 
some of the nutrient decline noted during drawdown. Studies are continuing to assess the nutrient levels in Par Pond (see Section 3.3).

The implementation of the proposed action could result in the reduction of nutrients entering Par Pond from the Savannah River. The reduction in nutrient load from the Savannah River is expected to change the species composition in Par Pond when compared to the population which existed over the 33 years of almost continuous nutrient input. Tilly (1975) found that Par Pond exhibited a sixfold increase in plankton primary productivity from 1965 to 1973 which was correlated with nutrient input from the make-up water being pumped from the Savannah River. The reservoir is expected to transition from a highly productive state to a water body that more resembles typical southeastern reservoirs that do not experience substantial nutrient input: Extensive sampling of water quality and biota in Pond B for many years (isolated part of the Par Pond system receiving no river flow for many years or subject to the drawdown impacts) indicates that Par Pond will likely become a similar ecosystem with much lower productivity and potentially higher Cs-137 uptake rates after the implementation of the proposed action (Whicker et al., 1993a),

\section{Aquatic and Terrestrial Biota}

One of the most noticeable impacts of the reservoir drawdown was the decimation of many beds of freshwater mussels and clams (Whicker, 1991a; DOE, 1992). 'This had an impact on the waterfowl population causing them to leave the area in larger numbers as these organisms were a major food source. Observations over the three years since drawdown show that waterfowl appear to be recovering in the reduced areas of the reservoir. These populations are expected to recover with the reservoir being full, however, some losses are expected in the wash zone and in areas where the sediments would be exposed if fluctuations reach downward to $58.2 \mathrm{~m}(195 \mathrm{ft})$ for an extended period of time.

Fish populations were temporarily impacted and severely reduced as a result of the drawdown. The absence of an established littoral zone was expected to have the potential for a total loss of recruitment because of significantly reduced spawning and nursery habitat. Although recruitment was significantly reduced, limited sampling data indicate that most species, including some shortlived forage species experienced some recruitment. This occurred in spite of the loss of the original littoral zone and probable intense predation. It is expected that the fish population would be somewhat reduced under the fluctuating water conditions with less spawning habitat available and reduced production. However, populations are expected to be more similar to those found in other southeastern reservoirs where water levels vary with season and hydrological conditions.

Fluctuations in water level occur naturally in many types of bodies; aquatic organisms are often adapted to survive in such conditions and may benefit from them (Nikolsky, 1963). In recognition of this fact, biologists often artificially fluctuate water levels in reservoirs to increase fish standing crop (Lantz et al., 1964), alter species composition (Hulsey, 1958), and enhance the spawning success of some species of fish (Richardson, 1975). However, the timing and magnitude of the fluctuations can reduce fish habitat and thereby reduce fish abundance (Gaboury and Patalas, 1984). Reductions in water level during the spring spawning months can deny spawning areas to species that normally spawn in shallow water (Gaboury and Patalas, 1984). However, moderate fluctuations that approximate natural changes in water regime (i.e., reductions in late summer and fall and increases in late winter and spring) can enhance the spawning súccess of some species by making more aquatic habitat available for spawning and nursery functions during the reproductive period.

In addition to being used to manage fish populations, reservoir water levels are often fluctuated to control and manipulate aquatic plant communities. Results are variable depending upon the timing and length of the drawdown and the geographic area (Cooke et al., 1986). However, in the 
Southeast reductions in water level during the winter and possibly during the summer have been demonstrated to effectively decrease the abundance of some species although others may benefit from drawdown periods (Lantz et al., 1964). In the latter category, for example, are cattail and bulrush which must have bare mudflats as a seedbed.

The effects of fluctuating water levels on water quality are uncertain. Large drawdowns may promote winter kill in far northern lakes or summer kill of fishes (due to oxygen depletion) in southern lakès. Less extensive fluctuations have variable effects although several researchers have observed algae blooms after reflooding reservoirs that have been drawn down (Hulsey, 1958; Beard, 1973). It has been hypothesized that such blooms are the result of nutrient release from previously exposed sediments, although experimental evidence for this theory is lacking (Fox et al., 1977).

From studies conducted on Par Pond, there is no evidence that the drawdown adversely affected the winter survival of adult alligators and little impact is expected from the fluctuating water level. However, there were unfavorable conditions for nesting and there was a low survival of juveniles due to loss of cover. The proposed action would have much less impact than drawdown but lack of cover and shoreline stability could affect the survival of juveniles.

Waterfowl use of Par Pond is expected to be reduced compared to full pool due to the slightly smaller area and somewhat reduced food resources. The number of birds overwintering on the reservoir increased as the reservoir water level increased after drawdown, in part due to recovered aquatic macrophyte and invertebrate populations in the basin.

The fluctuation of the water.levels to the $58.2 \mathrm{~m}$ (195 ft) level would still allow wildlife access to some of the exposed sediments at times, but potential impacts and increases in risk will be far less than the potential observed during the three years of the drawdown as sediments in this area are the least contaminated (Winn, 1993).

Substantial numbers of mourning dove (Zenaida macroura) have been observed foraging on the vegetation which had colonized the exposed lakebed before refill. Concern for the potential off-site transport of contaminants by these birds prompted an analysis of birds collected both on the sediments and offsite. These studies have revealed detectable levels of mercury and radiocesium in the birds foraging on the lakebed; however, these body burden levels were below levels of concern for human consumption. Although there has been no evidence of harm to wildlife from uptake of Cs-137 or mercury, there has been a noticeable increase in the uptake of cesium in some animals and vegetation located on the sediments. With increased uptake of contaminants, there is greater risk of physiological harm.

Fluctuation of the water levels is expected to have no impact on bald eagles. Par Pond has been and continues to be the location where most sightings of bald eagles on SRS takes place (Mayer et al., 1985; 1986; Wike et al., 1994). In general, the use of the reservoir by bald eagles has been for both foraging and roosting activities. The drawdown had no noticeable impact on the bald eagle use of Par Pond. It is assumed that most prey obtained by breeding adults and newly-fledged immatures are obtained in and around Par Pond. A slight increase in both radiocesium and mercury may occur as a result of the fluctuation of the water level but would be much less than drawdown and is thus not expected to impact bald eagles.

\section{Ecological Risks}

A limited, qualitative ecological risk assessment (WSRC, 1992) was conducted to determine the potential effect of exposure to contaminated sediment on the newly emerging (early successional) terrestrial community inhabiting the 1340 acres exposed from the drawdown of Par Pond to $54 \mathrm{~m}$ 
(180.2 ft). Results indicate that Cs-137 and mercury levels in the exposed sediments potentially impact the biotic receptors that inhabit the Par Pond shoreline; however, little or no effects to either terrestrial or aquatic vegetation were observed. Even less impacts are expected within the area potentially exposed by the proposed action. A relatively small portion of the contaminated sediments will be exposed under natural water level fluctuations in the reservoir. The lowest predicted (modeled) water level of 58.8 (196.2 ft) will result in the maximum exposure of approximately 340 acres [(about 500 acres at $58.2 \mathrm{~m}$ (195 ft)], while less than approximately 115 acres of contaminated sediments will be exposed about 35 percent of the time (Figure 5).

Since most of the radionuclide releases to Par Pond occurred during the 1950 to 1960 era, and half-life of Cs-137 is approximately 30 years, more that half of this radionuclide has decayed. The current estimated inventory of Cs-137 associated with all sediments within the Par Pond reservoir is approximately $43 \mathrm{Ci}$ (Winn, 1993), of which $9 \mathrm{Ci}$ were present in the 1340 acres of exposed sediments after drawdown. The area of continuously exposed sediments under the proposed action would be much less, representing only a small fraction of Cs-137 inventory and subsequent potential risks.

\section{Human Health Risks}

Existing human populations that potentially may be exposed to contaminants in Par Pond include residents living outside but near the eastern boundary of SRS or downstream in the Lower Three - Runs and Savannah River watersheds, trespassers who may enter the Par Pond area, and workers involved with ongoing activities. Exposure pathways through which human receptors could be potentially exposed include external exposure to radiation from exposed sediments, inhalation of airborne sediment particulates, and dermal contact with and ingestion of sediments. The drawdown of Par Pond exposed approximately 1340 acres of previously submerged sediments that were previously under water. A limited human health risk assessment was conducted (WSRC, 1992), based on limited existing data to address the human health risks resulting from the exposed sediments at the $54 \mathrm{~m}(180.2 \mathrm{ft})$ level.

Carcinogenic risks from inhalation of airborne sediment particulates by residents outside SRS boundaries was found to be of little concern, as the estimated risk was less than the EPA target risk range of $1 \times 10^{-6}$ (one excess cancer in one million people). Carcinogenic risks calculated for the current land use scenario indicated only one pathway, external exposure from sediment to the $\mathrm{Par}$ Pond unit worker, exceeded the EPA-established target risk $1 \times 10^{-6}$, the risk for this pathway was calculated to be $4 \times 10^{-5}$, within the EPA target risk range. By managing work conditions and duration of exposure, this risk can be minimized.

Carcinogenic risks calculated for the hypothetical future Par Pond unit worker $\left(5 \times 10^{-3}\right)$ and future $\mathrm{Par}$ Pond unit resident exposed to $\mathrm{Par}$ Pond sediments $\left(2 \times 10^{-2}\right)$ indicated that risks exceeding the EPA-established target range of $1 \times 10^{-4}$ to $1 \times 10^{-6}$ are likely for these scenarios. Because of the hypothetical nature of the Par Pond unit resident scenario, the additional pathways that were identified by this scenario are not likely to be of concern in the immediate future. However, the results of this scenario do identify additional pathways of concern should the Par Pond unit resident conditions become a possibility.

The operational and monitoring activities associated with exposed sediment will result in an increase in the frequency and length of time which on-site workers are spending in Par Pond. As such, concerns exist with respect to increased radiation exposures to these workers because of the radioactivity in the exposed sediments. Potential occupational impacts to SRS employees working at Par Pond would be by means of three pathways including atmospheric, liquid, and external exposure (Marter and Boni, 1991). 


\section{Atmospheric}

Effects resulting from the inhalation of airborne sediments from the exposed and drying. contaminated lakebed by on-site workers at Par Pond were determined to be insignificant for the exposed sediments at the $54 \mathrm{~m}(180.2 \mathrm{ft})$ level. Based on core samples taken in the exposed lakebed, the upper layer sediments that could become windborne are not likely to have Cs-137 concentrations greater than $60 \mathrm{pCi} / \mathrm{gm}$ (Marter and Boni, 1991; Whicker, 1991b). The committed effective dose equivalent (CEDE) from the inhalation of $1 \mathrm{pCi}$ of Cs-137 is $3.2 \times 10^{-5}$ mrem (Marter and Boni, 1991). In order to receive a CEDE of 1.0 mrem from the inhalation of sediments from $\mathrm{pCi}, 520$ grams (1.2 pounds) of airborne sediments containing $60 \mathrm{pCi} / \mathrm{gm}$ of Cs-137 must be ingested. The CEDE for an onsite employee working at Par Pond for one year would be $0.05 \mathrm{mrem}$ (Marter and Boni, 1991).

\section{Liquid}

The average radioactivity concentrations for Cs-137 (3.5 pCi/L) in Par Pond is well below the EPA standards (40 CFR 141) of $200 \mathrm{pCi} / \mathrm{L}$ for public drinking water. Consumption by an on-site worker of a liter of water from Par Pond would result in CEDE of 0.0003 mrem. However, it is not expected that workers would consume pond water and CEDE from this pathway will be negligible (Marter and Boni, 1991).

\section{External}

External gamma exposure rates from areas in the exposed portion of the lakebed averaged 8 $\mathrm{uR} / \mathrm{hr}$ (Whicker, 1991b). An annual exposure to an onsite employee working 5040 -hour weeks on the exposed sediments of Par Pond would be 16 mrem (Marter and Boni, 1991).

In summary, human health impacts associated with SRS employee radiation exposure in the Par Pond basin are not significant (Hamby, 1991; WSRC, 1992).

The limited risk assessment indicated no adverse noncarcinogenic human health effects are likely from exposure to Par Pond sediments (WSRC, 1995). EPA and SCDHEC approved the preferred CERCLA alternative of refilling Par Pond as an interim action (WSRC, 1995). Once refilled, the overlying water effectively shields the gamma radiation emissions from Cs-137.

Human access to Par Pond will continue to be strictly controlled by DOE and workers time limit on any exposed sediments will be closely monitored. Winn (1993) measured Cs-137 concentrations in sediments of Par Pond from approximately $58.2 \mathrm{~m}(194.2 \mathrm{ft}$ ) $\mathrm{msl}$ to the bottom of the reservoir and estimated an inventory of Cs-137 in the reservoir from these measurements. He estimated that of the approximately $9.4 \mathrm{Ci}$ of Cs-137 in the sediments between about $54 \mathrm{~m}(180.2 \mathrm{ft})$ and $58.8 \mathrm{~m}$ (196.2 ft), only about $3.3 \mathrm{Ci}$ occurred in sediments above about $56.7 \mathrm{~m}(189.2 \mathrm{ft}$ ), although approximately 58 percent of the exposed surface area was above about $56.7 \mathrm{~m}(189.2 \mathrm{ft})$. Because the primary pathway of concern for workers on Par Pond is external exposure to gamma radiation from Cs-137 in the exposed sediments, the lower concentrations and inventory of Cs-137 in these sediments in the upper elevations of the basin will result in a substantially lower risk than that when the reservoir was at $54 \mathrm{~m}(180.2 \mathrm{ft})$. Human health risks within the potentially exposed area of the proposed action is therefore expected to be insignificant. Similarly, exposures to organisms inhabiting these sediments will also be substantially lower than would have occurred with the water level at $55.8 \mathrm{~m}(180.2 \mathrm{ft})$. The results from aerial gamma radiation surveys conducted when the reservoir was at $55.8 \mathrm{~m}(186.2 \mathrm{ft})$ and $54 \mathrm{~m}(180.2 \mathrm{ft})$ confirm that exposure rates are substantially lower when the reservoir water level is above $54 \mathrm{~m}$ (180.2 ft); average gamma radiation count rates 
for Cs-137 (dose) at $56.8 \mathrm{~m}$ (186.2 ft) pool level were approximately half ( 55 percent) of the rates at $54 \mathrm{~m}(180.2 \mathrm{ft})$ pool level (Fiemster, 1993).

The P-Reactor canal system has not been surveyed or sampled in detail. Aerial gamma overflight data reveals low levels of gamma emitting radionuclide contamination in the canal system with the exception of Ponds 4 and 5 (Fiemster, 1993). These ponds are in the original drainage path from R-Reactor to Lower Three Runs and received releases prior to the construction of Pond B. The cessation of water discharge into the canal system is not expected to result in the total drying of the pre-cooler ponds. These ponds were constructed by impounding natural drainages and will continue to receive rainfall, and surface and near-surface runoff from the drainage area. However, in cases of extreme drought, these ponds may dry. The canals leading from this pond to Pond $\mathrm{C}$ may dry frequently. Although some sampling has been conducted in these canals, the historically high flows through these small canals should result in the accumulation of little contamination because the soil particles containing the contaminants would be scoured and transported into the downstream ponds and reservoirs.

\subsubsection{Lower. Three Runs}

The flow in Lower Three Runs has been regulated by the discharge from Par Pond since 1958 . Discharge to Lower Three Runs has varied over the years due to changes in reactor operation and water levels in Par Pond. The U.S. Geologic Survey (USGS) has measured flow in Lower Three Runs below the dam (USGS \#02197830) and at Patterson Mill (USGS \#02197400) since Water Year (October-September) 1974. The station below Par Pond did not operate during Water Years 1983-1986. The average flows below the dam and Patterson Mill for the periods of record are 1.1 $\mathrm{m}^{3} / \mathrm{sec}\left(37 \mathrm{ft}^{3} / \mathrm{sec}\right)$ and $2.5 \mathrm{~m}^{3} / \mathrm{sec}\left(85 \mathrm{ft}^{3} / \mathrm{sec}\right)$, respectively. Excluding the years when the station below the dam was not operational, the average flow at Patterson Mill was $2.6 \mathrm{~m}^{3} / \mathrm{sec}\left(87 \mathrm{ft}^{3} / \mathrm{sec}\right)$. Since P-Reactor is no longer operating, it is not necessary to operate Par Pond as a recirculating cooling system. Consequently, it is possible to significantly reduce operating costs by pumping less water into Par Pond. This action would then reduce the discharge of water to Lower Three Runs. Reduction in Lower Three Runs could have impacts on the aquatic life and habitat indices such as depth, cross sectional area, and velocity: The greatest impacts to Lower Three Runs are expected in the reach of stream immediately downstream for the dam where flow is almost entirely regulated by Par Pond discharge (del Carmen and Paller, 1993).

The optimal solution to this problem is the determination of a discharge rate that will protect the aquatic life as well as reduce the costs associated with pumping river water to the Par Pond/Lower Three Runs system. Del Carmen and Paller (1993) conducted an instream flow study on Lower Three Runs to identify a discharge rate from Par Pond that will protect aquatic life in the stream and allow for the reduction of pumping water inflows to Par Pond. The Physical Habitat Simulation (PHABSIM) system of the U.S. Fish and Wildlife Service's (USFWS) Instream Flow Incremental Methodology (IFIM) was used to develop the habitat versus discharge relationships. Under high and low-flow conditions, measurements of water surface elevation, discharge, and velocity were taken in three reaches, Road B, Donora Station, and Patterson Mill. Following calibration, the Water Surface Profile (WSP) model was used to simulate water surface elevations for a range of discharges at each reach. The "AVDEPTH" habitat model produced depth, width, cross sectional area, and velocity data for different discharges. Simulated depths and velocities were compared with a sample of depth and velocity data measured in variously sized SRS streams. From this analysis and information on the fish assemblage structure in SRS streams, they concluded that a base flow of approximately $0.28 \mathrm{~m}^{3} / \mathrm{sec}\left(10 \mathrm{ft}^{3} / \mathrm{sec}\right)$ in the reach of Lower Three Runs below the $\mathrm{Par}$ Pond dam is sufficient to support a biologically balanced fish community commensurate with a first/second order stream community. 


\subsection{L-Lake and Steel Creek}

Part of the proposed action is to assess the environmental impacts of reducing flows from L-Lake Dam to Steel Creek to base flows and therefore reducing the amount of water must be pumped. The reduction of river water input to L-Lake will result in reduced nutrient input to the reservoir, however, the approximately 80 percent reduction in water release from L-Lake is not expected to result in a comparable reduction in nutrient input. Some nutrients are contained in surface runoff and groundwater input into the reservoir. Overall, a significant but unquantified reduction in nutrient input is expected that will result in reduced primary and secondary productivity in L-Lake. Consequently, the basin is expected to shift from a eutrophic classification to a less eutrophic, or even mesotrophic, classification.

The maintenance of stable water levels in L-Lake should result in continued development of macrophyte communities, thereby providing habitat and foraging resources for aquatic, semiaquatic and water fowl resources that currently occupy or utilize the reservoir. Thus, the shorezone communities are not expected to experience significant adverse impacts as a result of the proposed action. However, some reduction in macrophyte productivity or expansion rate might occur. Section 1.2.4 provided the background and the L-Reactor EIS commitments (DOE, 1984; 1990) for maintaining minimum flows of approximately $1.5 \mathrm{~m}^{3} / \mathrm{sec}(53 \mathrm{ft} / \mathrm{sec})$ year-round.

The L-Reactor has been placed in a cold-shutdown condition and historical high reactor discharges will not occur. Evaluation of the Steel Creek ecosystem prior to the resumption of L-Reactor operations in 1985 indicated that stream morphometry and biotic structure had progressed significantly toward adapting to the natural flow regime from the high flow regimes experienced until 1968 (DOE, 1984). It is anticipated that accommodation to a reduced flow regime would also occur if flows are reduced from current requirements. However, the complete elimination of minimum flow requirements could lead to an unnatural flow regime because L-Lake intercepts all drainage from the upper Steel Creek Basin. Low flow related problems could be particularly severe in the portion of Steel Creek downstream from the dam and upstream from Meyers Branch. Therefore, it would be advantageous to determine optimal flow requirements that maintain the ecological integrity of Steel Creek without expenditure for unnecessary water pumping (MooreShedrow, 1992).

Del Carmen and Paller (1993) conducted a hydrologic and fishery evaluation study of the effects of flow reduction on Steel Creek habitat. In this study, the historical natural flow in Steel Creek below L-Lake dam was estimated by comparison with a similarly sized drainage area in Pen Branch watershed and by extrapolation from a smaller drainage area within the Steel Creek wetland. The historical natural flow in Steel Creek below L-Lake is approximately $0.28 \mathrm{~m}^{3} / \mathrm{sec}$ $\left(10 \mathrm{ft}^{3} / \mathrm{sec}\right)$. A reduction in L-Lake discharge to historical base flow levels of approximately 0.28 $\mathrm{m}^{3} / \mathrm{sec}\left(10 \mathrm{ft}^{3} / \mathrm{sec}\right)$ is likely to result in reduction in stream morphology to levels that are likely to favor those species of fish typical of first and second order streams. The L-Reactor EIS (DOE, 1984) minimum flow requirements were designed to mitigate against dewatering of these stream margin areas thus preventing the potential loss of fish larvae and eggs and invertebrate populations. Since L-Reactor will not operate again and cause consistent high flows in Steel Creek, the high spring flow of $3 \mathrm{~m}^{3} / \mathrm{sec}\left(106 \mathrm{ft}^{3} / \mathrm{sec}\right)$ requirement was eliminated as one step in restoring Steel Creek to a more natural hydrologic state (Wright, 1994).

Del Carmen and Paller (1993) point out that the result of reducing the required flow down to the historical flow of $0.28 \mathrm{~m}^{3} / \mathrm{sec}\left(10 \mathrm{ft}^{3} / \mathrm{sec}\right)$ would be a fish community similar to the one that existed in Steel Creek prior to the impoundment of L-Lake. This conclusion was based on extensive sampling of Steel Creek species assemblages prior to the construction of L-Lake. No 
significant impacts are expected on wetlands or on the fish population along the Steel Creek corridor as a result of reducing the flows from the year-round commitment of $1.5 \mathrm{~m}^{3} / \mathrm{sec}$ (53 $\left.\mathrm{ft}^{3} / \mathrm{sec}\right)$ and $3 \mathrm{~m}^{3} / \mathrm{sec}\left(106 \mathrm{ft}^{3} / \mathrm{sec}\right)$ during the spawning in season to $0.28 \mathrm{~m}^{3} / \mathrm{sec}\left(10 \mathrm{ft}^{3} / \mathrm{sec}\right)$ based on these detailed studies (del Carmen and Paller, 1993). The $0.28 \mathrm{~m}^{3} / \mathrm{sec}\left(10 \mathrm{ft}^{3} / \mathrm{sec}\right.$ ) is an average flow and its calculation included data from $1984-1992$ which encompassed drought years. During storm periods significantly higher flows could be expected due to storm runoff. Also there is no regulatory requirement to continue pumping of water into L-Lake and cessation of discharge would likely lead to the L-Reactor discharge being removed from the National Pollutant Discharge Elimination System permit (Gould, 1993).

Reducing the flow to Steel Creek to minimum historical flows reduces the pumping demand to LLake. This reduction is from one pump running continuously and another running 40 percent of the time to just one pump per year or $1.5 \mathrm{~m}^{3} / \mathrm{sec}(53 \mathrm{ft} / \mathrm{sec})$. The elimination of the additional pump operation would result in a net annual savings of approximately $\$ 570,000$ in pumping costs.

In summary, the proposed action would save approximately $\$ 930,000$ total in annual incremented electrical costs.

\subsection{Monitoring Par Pond Water Level and L-Lake/Steel Creek Flow Reduction}

Monitoring is ongoing as part of the Par Pond CERCLA Record of Decision (WSRC, 1995). This includes responses of the dam to fluctuating water levels as well as ecological conditions in the reservoir. Also included is monitoring of water quality and Cs-137 both in the reservoir and of discharges from the reservoir to Lower Three Runs. This section describes the post-refill monitoring program. Should any of these parameters exceed established threshold levels during implementation of the proposed action, water would again be pumped into the reservoir to minimize any impacts by bringing the water level back to an appropriate level above $58.2 \mathrm{~m}$ (195 $\mathrm{ft})$.

\section{Hydrology}

Water levels in and discharges from Par Pond are monitored continuously by the USGS. Water levels in and discharges from L-Lake are also monitored continuously. Rainfall is measured at least two locations near Par Pond. These data will be used to evaluate the performance of Par Pond water levels versus the model predictions. Modeling studies to date have not incorporated groundwater flux into and out of the reservoir. Groundwater level data will be acquired for areas surrounding the reservoir and the net flux of groundwater evaluated. These data will be incorporated into a revised model of the reservoir hydrology and the model results verified against actual reservoir performance.

\section{Water Quality}

The reduction in river water input to L-Lake and Par Pond may result in changes in water quality within the reservoirs that may alter the ecological functioning of these ecosystems. During 1995, water quality will be monitored in Par Pond and in Lower Three Runs twice monthly at four locations that have been used in previous monitoring programs. During 1996, water quality will be monitored in Par Pond monthly at these same locations. Water quality will be monitored in Steel Creek. Top and bottom samples will be collected and analyzed for nutrients and chlorophyll a. Dissolved oxygen, temperature and $\mathrm{pH}$ will be measured at more frequent depth intervals to identify the depth of the thermocline and characterize conditions in the epilimnion and hypolimnion during periods of stratification. 
Measurements of Cs-137 and mercury will be made in reservoir water on a quarterly basis . during 1995 and 1996.

\section{Sediments}

In 1995, sediments in Par Pond will be sampled to evaluate contaminant concentrations. Cores will be taken within each reservoir and analyzed for an extensive suite of metals and radionuclides, as well as other soil properties (e.g. textural analysis and organic carbon).

\section{Vegetation}

The shore-zone macrophyte community will be evaluated quarterly during the growing season to determine the extent of macrophyte community development and the species composition of that community. This sampling will be conducted in 1995 through 1997. Ground level evaluations will be supplemented by aerial remote sensing data.

\section{Fisheries}

Fish community structure, Cs-137, and mercury contaminant levels have been monitored during the Par Pond refill and will be monitored at least annually in Par Pond during 1995, 1996, and 1997. Changes in fish community structure and size distribution will be assessed to evaluate changes in productivity, recruitment and trophic structure.

\subsection{Environmental Consequences of the Alternatives}

Under the no action alternative, SRS would continue to pump water from the Savannah River to Par Pond to keep the reservoir level at full pool. The water level would shield all the Cs-137 in the reservoir's sediments thus eliminating potential risks from exposed sediments. This action would also allow the continuing recovery of the reservoir's ecosystem similar to its previous 33 years of stable conditions before drawdown. Continuous pumping of nutrients from the Savannah River would assure continued high productivity and diverse species composition and relative abundance. No action also includes continuing to pump river water to L-Lake to maintain full pool and maintain the current $1.5 \mathrm{~m}^{3} / \mathrm{sec}\left(53 \mathrm{ft}^{3} / \mathrm{sec}\right)$ in Steel Creek. The total estimated electrical annual pumping cost of the no action alternative is $\$ 930,000$.

The preferred alternative to reduce pumping to Par Pond and allow the water level to fluctuate naturally between full pool and $58.2 \mathrm{~m}(195 \mathrm{ft})$ would have an impact on the reservoir's ecosystem through a reduction in nutrients from the Savannah River. This will lower Par Pond's productivity, species composition and relative abundance, and potentially increase Cs-137 uptake. The reservoir's ecosystem is expected to revert to that typically found in the southeast. The littoral vegetative community and other species such as fish will be impacted in the wave-wash zone. This approximately 115 -acre area above $59.7 \mathrm{~m}(199.2 \mathrm{ft})$ represents only about 4.6 percent of the reservoir's total bottom area below full pool ( 2,640 acres) and about 20 percent of the bottom area between $58.2 \mathrm{~m}(195 \mathrm{ft})$ and full pool, the maximum projected fluctuation. Potential risks to human health or wildlife from Cs-137 in exposed sediments is expected to be insignificant because little impact was shown as a result of drawdown to the $54 \mathrm{~m}$ (180.2 ft) level. Only one third of the Cs-137 inventory of previously exposed sediments is above about $56.7 \mathrm{~m}(189.2 \mathrm{ft})$ level, and the reservoir should not fluctuate below the $58.2 \mathrm{~m}$ (195 ft) level.

The reduction in current flow to Steel Creek from L-Lake from $1.5 \mathrm{~m}^{3} / \mathrm{sec}(53 \mathrm{ft} 3 / \mathrm{sec})$ to 0.28 $\mathrm{m}^{3} / \mathrm{sec}\left(10 \mathrm{ft}^{3} / \mathrm{sec}\right)$ is not expected to cause any impacts on the balanced biological community in Steel Creek based on accepted in situ instream flow studies. The total electrical cost savings from 
reduced pumping by this alternative is estimated at about $\$ 930,000$ annually with a reduction in Site electrical use of about 2 percent.

Two other alternatives were also evaluated. One would eliminate pumping to $\mathrm{Par}$ Pond while continuing to maintain a $1.5 \mathrm{~m}^{3} / \mathrm{sec}\left(53 \mathrm{ft}^{3} / \mathrm{sec}\right)$ flow in Steel Creek below L-Lake. This would save about $\$ 360,000$ in pumping electrical costs and would not allow continued recovery of the Par Pond ecosystem to pre-drawdown conditions. This would create a less productive reservoir which would be similar to other reservoirs in the southeast.

The other alternative would continue to pump river water to Par Pond but reduce the discharge to Steel Creek from L-Lake from $1.5 \mathrm{~m}^{3} / \mathrm{sec}\left(53 \mathrm{ft}^{3} / \mathrm{sec}\right)$ to $0.28 \mathrm{~m}^{3} / \mathrm{sec}\left(10 \mathrm{ft}^{3} / \mathrm{sec}\right)$ saving about $\$ 570,000$ in annual pumping costs. The potential environmental impacts would be about the same as for the no action alternative as reducing the flow in Steel Creek to base flow conditions is not expected to have any significant impact on the stream biota.

\subsection{Other Impacts}

\subsubsection{Safeguards and Security}

All safeguard and security measures required by the applicable DOE orders would continue to be provided for the on-site facilities associated with Par Pond and L-Lake and the river water system. Access to Par Pond is restricted because it is a CERCLA unit.

\subsubsection{Emergency Planning}

DOE has developed a series of emergency response plans with the cooperation of state and county. agencies to comply with DOE order 5500 series emergency preparedness orders to respond to any on-site incidents at SRS.

\subsection{Cumulative Impacts}

The principle cumulative impact of the proposed action would be the reduction in the Site's electrical load. Based on the forecasted FY95 Site electrical consumption of 542,000 MW-hrs., the elimination of running an additional pump half of the time would decrease the Site's electrical consumption by 2.0 percent.

\subsection{REGULATORY AND PERMITTING CONSIDERATIONS}

It is DOE policy to carry out its operations in compliance with all applicable federal, state, and local laws and regulations, as well as all DOE Orders. This section provides a discussion of the major regulatory permit programs that might be applicable to the proposed action.

\subsection{National Environmental Policy Act of 1969, as amended (42 USC 4321 et seq.)}

The EA has been prepared in compliance with the NEPA of 1969, as amended, and the requirements of the Council of Environmental Quality Regulations for Implementing NEPA (40 CFR Parts 1500-1508), and DOE Regulations (10 CFR Part 1021), and DOE Order 5440.1E. NEPA, as amended, requires "all agencies of the Federal Government" to prepare a detailed statement on the environmental effects of proposed "major Federal actions significantly affecting the quality of the human environment." This EA has been written to comply with NEPA and to 
assess the potential environmental impacts of the natural fluctuation of water levels in Par Pond and reduced water flow in Steel Creek below L-Lake Dam at SRS.

\subsection{Wetlands Regulations}

Section 1022.15 of 10 CFR requires that DOE design or modify its actions to minimize potential harm to or within wetlands or floodplains. In addition, Executive Order 11990 discusses the protection of wetlands. Drawdown activities have impacted wetland communities in both Par Pond and Lower Three Runs Creek. However, previous experience has demonstrated that wetland communities will reestablish themselves over a period of time, depending on the length and severity of the drawdown. Studies continue on the evaluation of the potential impacts to the subject wetland areas and to mitigate other impacts. DOE policy is to preserve and protect wetland resources at SRS in accordance with the national goal of "no net loss" of wetlands.

\subsection{Drinking Water Regulations}

No impacts from radiological releases have occurred on downstream water users and others based on Federal drinking water standards (Hayes, 1991; Marter and Boni, 1991) as a result of the drawdown. None will occur as a result of the implementation of the proposed action.

\subsection{Navigable Water Regulations}

An emergency permit for State navigable waters construction was obtained from the S.C. Water Resources Commission (SCWRC) in August 1991 after the Commission determined that the proposed dam repair was necessary to protect the health and public safety. South Carolina Department of Natural Resources (formally SCWRC) has been notified of the completion of the dam repair project.

\subsection{Clean Water Regulations}

Clean Water Act requirements were not impacted by the drawdown, repair, and refill activities at Par Pond. The repair of the Par Pond dam with partial drawdown of the reservoir was authorized by the U.S. Army Corps of Engineers (COE) under a nationwide permit as repair of a previously authorized, currently serviceable structure. No additional permit was required to refill Par Pond to the original full pool water level. The COE does not consider the drawdown or restoration of lake water levels to be within their jurisdiction in as much as no dredging or filling activities were required (WSRC, 1992).

In accordance with the Clean Water Act (CWA) Section 404, approval from the COE and SCWRC was obtained for rip rap activities conducted in the floodplain of Lower Three Runs Creek immediately downstream of the dam. There is no detailed reference to a flow requirement in permits or site documents. There is a regulatory requirement to maintain minimum flows which would provide for the survival and propagation of a balanced aquatic community.

Under the broad definition of the CWA, Section 502 (19), man-induced-alteration of streamflow levels are considered "pollution". Further, South Carolina Water Classification and Standards Regulation 61-68 (D)(1)(b) states, "...the streamflows necessary to protect classified and existing uses and the water quality supporting these uses shall be maintained consistent with riparian rights to reasonable use of water". These standards become Applicable and Relevant Requirements (ARARS) under CERCLA and necessarily must be considered when making plans for the shutdown of river water system. 
Those portions of Steel Creek below L-Lake Dam and Lower Three Runs below Par Pond Dam are classified as "Freshwaters" under Regulation 61-68. Specific water quality standards apply to this classification such that these waters are"...suitable for fishing and the survival and propagation of a balanced indigenous aquatic community of fauna and flora". Additionally, Lower Three Runs is a state designated navigable water. A recently released SCDHEC report (Watershed Water Quality" Management Strategy) listed Steel Creek water quality as being fully supportive of the aquatic life and recreational uses. Lower Three Runs is listed as an impacted water body from non-point sources and is included by the State in a CWA Section 304 (1) list of impacted waterbodies for point source concerns for toxic pollution (Roberts, 1993).

\subsection{Clean Air Regulations}

Airborne releases from the sediments have not exceeded NESHAP standards (40 CFR 61 Subpart $\mathrm{H}$ ) and no impacts have been shown as a result of airborne releases from the exposed sediments (Marter and Boni, 1991) after drawdown. No impacts would occur from the proposed action.

\subsection{Comprehensive Environmental Response, Compensation and Liability Act (CERCLA) Waste Regulations}

Par Pond is on the SRS CERCLA Site Evaluation List in the FFA and required investigation under CERCLA. Due to the contamination of the exposed lakebed sediments, there was a potential that the Cs-137 could impact human health. A human health and ecological risk assessment was performed and an IAPP was developed and reviewed by the public which evaluated the various remediation technologies and costs associated with numerous cleanup options and their associated impacts. Refill of Par Pond was the preferred alternative. EPA, SCDHEC, and DOE signed an Interim Record of Decision (IROD) under which the parties selected the preferred alternative of refilling Par Pond. The preferred alternative of refilling Par Pond was an interim action to be used until a more permanent remedial strategy could be formulated, evaluated, and employed. In fact, the IROD specifically contemplated, in large part as a result of public participation, that refill to 60 $\mathrm{m}+/-0.3 \mathrm{~m}(200 \mathrm{ft}+/-1 \mathrm{ft})$ would be an interim action until a strategy, similarly protective of human health but based on more complete data, could be evaluated. This EA is the means by which the evaluation of these strategies is to be initiated. Consequently, this EA is within the scope and is supportive of the human health, environmental, and cost saving objectives of the IROD. 


\subsection{REFERENCES}

Beard, T. D. 1973. Overwinter Drawdown. Impact on the Aquatic Vegetation in Murphy Flowage, Wisconsin, Tech. Bull. No. 61, Department of Natural Resources, Madison, WI.

Bowers, J. A. 1992. Synoptic Surveys of Major Reservoirs in South Carolina, 1988-1989 (U). WSRP-RP-92-368. Westinghouse Savannah River Company, Savannah River Technology Center, Aiken, SC.

Boyd, C. W. 1970. Production, Mineral Accumulation, and Pigment Concentrations in Typha latifolia and Scirpus americanus, Ecology, 51: 285-290.

Brisbin, I. L., Jr., M. Brenner, L. A. Brandt, R. A. Kennamer, and T. M. Murphy. 1992. Long-Term Population Studies of American Alligators Inhabiting a Reservoir: Initial Responses to Water Level Drawdown. Proc. of the 11th Working Meeting of IUCN/SSC Crocodile Specialist Group. Gland, Switzerland.

Bryant, E. L. 1995. "L-Lake Pumping Cost". Interoffice Memorandum. E. L. Bryant to A. C. Doswell, Feb. 16, 1995, Westinghouse Savannah River Company, Savannah River Site, Aiken SC.

Cooke, G. D., E. B. Welch, S. A. Peterson, and P. R. Newroth. 1986. Lake and reservoir restoration. Butterworths, Boston, MA.

del Carmen, B. R. and M. H. Paller. 1993. Hydrologic Analysis of Steel Creek and L-: Lake and the Effects of Flow Reduction on Steel Creek Habitat (U). WSRCTR-93-644. Westinghouse Savannah River Company, Savannah River Site, Aiken, SC.

DOE (U.S. Department of Energy). 1984. Final Environmental Impact Statement. LReactor Operations, Savannah River Plant. DOE/EIS-0108, Savannah River Operations Office, Aiken, SC.

DOE (U.S. Department of Energy). 1990. Final Environmental Impact Statement. Continued Operation of K-, L-, and P-Reactors, Savannah River Site. DOE/EIS-0147, Savannah River Operations Office, Aiken, SC.

DOE (U.S. Department of Energy). 1992. Special Environmental Analysis for Par Pond at the Savannah River Site. U.S. Department of Energy, Savannah River Field Office, Aiken, SC.

DOE (U.S. Department of Energy). 1993. Supplement Two to Par Pond Special Environmental Analysis, Observed Environmental Impacts. Savannah River Operations Office, Savannah River Site, Aiken, SC.

DOE (U.S. Department of Energy). 1994a. Final Supplemental Impact Statement for the Defense Waste Processing Facility, Savannah River Site. DOE/EIS0082-S, Savannah River Operations Office, Aiken, SC.

DOE (U.S. Department of Energy). 1994b. The Savannah River Operations Office Strategic Plan. Savannah River Operations Office, Savannah River Site, Aiken, SC. 
DuPont (E. I. du Pont de Nemours and Company). 1987. Comprehensive Cooling Water Study. Volume III: Radionuclide and Heavy Metal Transport. M. W. Lower (ed). DP1730-3, Savannah River Laboratory, Aiken, SC.

Feimster, E. L. 1993. A Comparison of Four Aerial Radiological Surveys of Par Pond and the Surrounding Area, Savannah River Site, Aiken, SC. EG\&G Energy Measurements, EGG 11265-1009, EG\&G, Inc.

Fox, J. L., Brezonick, P. L., and M. A. Keirn. 1977. Lake drawdown as a method of improving water quality, EPA-600/3-77-005.

Gaboury, M. N., and Patalas, J. W. 1984. Influence of water-level drawdown on the fish populations of Cross Lake, Manitoba. Can J. Fish. Aquatic Sci., 41:118125.

Gladden, J. B., M. H. Paller, and H. E. Mackey. 1995. NEPA Support Documentation for Par Pond and L-Lake (U). Interoffice Memorandum. SRT-ESS-95-0245. Westinghouse Savannah River Company, Savannah River Site, Aiken, SC.

Gladden, J. B.; W. L. Specht, J. A. Bowers, N. V. Halverson, H. E. Mackey, and E. W. Wilde. 1988. Compliance of the Savannah River Plant L-Reactor Cooling System with Environmental Regulations - Demonstration in Accordance with Section 316(a) of the Clean Water Act, November 1985 - December 1987. DP-1766, E. I. du Pont de Nemours and Company, Savannah River Laboratory, Aiken, SC.

Gould, A. B. 1993. Comments Regarding the Pumping of Water Through the LReactor Facility into L-Lake. Memorandum. Department of Energy, Savannah River Operations Office, Aiken, SC.

Hamby, D. M. 1991. Reasonable Maximum Risk Estimates for Par Pond. SRL-ETS910603. Westinghouse Savannah River Company, Savannah River Site, Aiken, SC.

Hammond, C. M. 1994. Site Dams and Cooling Water Systems. Interoffice Memorandum, C. M. Hammond to D. R. Spence, SSD-SUD-94-0006, Westinghouse Savannah River Company, Savannah River Site, Aiken, SC.

Hajyes, D. W. 1991. Inventory and Concentrations of Cs-137 and Tritium in Par Pond and Lower Three Runs Creek System. SRL-ETS-910327. Westinghouse Savannah River Company, Savannah River Site, Aiken, SC

Hulsey, A. H. 1958. A Proposal for the Management of Reservoirs for Fisheries. Proc. Southeast. Assoc. Game Fish Comm. 12:132-143.

Jensen, J. R., S. Narumalani, O. Weatherbee, and H. E. Mackey. 1.991. Remote Sensing Offers an Alternative for Mapping Wetlands. Geo. Info. Systems, 10:46-53.

Jensen, J. R., S. Narumalani, O. Weatherbee, and H. E. Mackey. 1993a. Measurement of Seasonal and Yearly Cattail and Waterlily Changes Using Multidate SPOT Panchromatic Data. Photogrammetric Engineering \& Remote Sensing. 59(4):519-525. 
Jensen, J. R., S. Narumalani, O. Weatherbee, and H. E. Mackey. 1993b. Remote Sensing Offers an Alternative for Mapping Wetlands. Geo. Info. Systems. October 1991. pp.46-53.

Lantz; K. E., J. T. Davis, J. S. Hughes, and H. E. Schafer. 1964. Water Level Fluctuation. - Its Effects on Vegetation Control and Fish Population Management. Proc. Southeast. Assoc. Game Fish Comm., 18:483-494.

Marcy, B. C., J. A. Bower, J. B. Gladden, H. M. Hickey, M. P. Jones, H. E. Mackey, and J. J. Mayer. 1994. Remediation of a Large Contaminated Reactor Cooling Reservoir: Resolving an Environmental/Regulatory Paradox. 19th Annual Proceeding of the National Association of Environmental Professionals, New Orleans, LA., pp.665-676.

Marshall, J. S., and J. H. LeRoy. 1971. Iron Manganese, Cobalt, and Zine Cycles in a South Carolina Reservoir, in Radionuclides in Ecosystems, Proceedings of the Third National Symposium on Radioecology, May 10-12, 1971, Oak Ridge, Tenn., D. J. Nelson (Ed.) USAEC Report CONF-710501-P1, pp.465-473.

Marter, W. L., and A. L. Boni. 1991. Summary of Radiological Impacts of Par Pond Drawdown. SRL-ETS-910579. Westinghouse Savannah River Company, Savannah River Site, Aiken SC.

Mayer, J. J., R. T., Hoppe, and R. A. Kennamer. 1985. Bald and Golden Eagles on the Savannah River Plant, South Carolina. The Oriole, 50(4):53-57.

Mayer, J. J., R. T. Hoppe, and R. A. Kennamer. 1986. Bald and Golden Eagles of the SRP. Savannah River Ecology Laboratory Report, SREL, UC-66e, Savannah River Ecology Laboratory, Aiken, SC.

Moore, Shedrow, D. B., 1992. "Flow Requirements Through L-Reactor"' Interoffice Memorandum, D. B. Moore-Shedrow to J. S. Roberts, SRT-ESS-92-0614, Westinghouse Savannah River Company Savannah River Site, Aiken, SC.

Narumalani, S. G. 1993. Classification and Modeling of Aquatic Macrophytes Using Remote Sensing and Geographic Information Systems, PhD Thesis, Department of Geography, University of South Carolina, Columbia, SC.

Nikolsky, G. V. 1963. The Ecology of Fishes. Academic Press, NY.

NUS (Halliburton NUS Environmental Corporation). 1992. Socioeconomic Characteristics of Selected Counties and Communities Adjacent to the Savannah River Site. July 1992. Halliburton NUS Corporation, Aiken, SC.

Richardson, L. V. 1975. Water level manipulation: a tool for aquatic weed control. Hyacinth Control J., 13:8-11.

Roberts, J. S. 1993. Site Dams and Reactor Cooling Water System (U). Interoffice Memorandum, J. S. Roberts to C. M. Hammond. ESH-ENV-93-0383, Westinghouse Savannah River Company, Savannah River Site, Aiken, SC. 
SREL (Savannah River Ecology Laboratory). 1991. Summary Report of Par Pond Research. Savannah River Ecology Laboratory (University of Georgia), Aiken, SC.

Tilly, L. J. 1975. Changes in Water Chemistry and Primary Productivity of a Reactor Cooling Reservoir (Par Pond). In:. Mineral Cycling in Southeastern Ecosystems. Proceedings of a symposium. Tech. Inf. Cen., Energy Research and Development Administration, F. G. Howell et al., Editors. 14p.

U.S. Army Corps. of Engineers (USCOE). 1994. Par Pond Reservoir Level Study. Project No. PC-2071.94.001. U.S. Army Corps of Engineers, Charleston, SC.

Whicker, F. W. 1991a. Observations on the Par Pond Drawdownn: a Summary to date. Savannah River Ecology Laboratory, Aiken, SC.

Whicker, F. W. 1991b. Radiological Implications of the Par Pond Drawdown, In: 1991 Summary Report of Par Pond Research. C. Ercolano, [ed.], Savannah River Ecology Laboratory, Aiken, SC.

Whicker, F. W., D. J. Niquette, and T. G. Hinton. 1993a. To Remediate or Not: A Case History. Proceedings of Health Physics Society of America. Coeur d'Alene, ID, pp.473-485.

Whicker, F. W., T. G. Hinton, D. J. Wiquette, and J. Seel. 1993b. Health Risks to Hypothetical Residents of a Radioactively Contaminated Lake Bed: Meeting the challenge: Environmental Remediation Conf., Dept. of Energy, Augusta, GA. October 24-28, 1993. Savannah River Ecology Laboratory, Aiken, SC.

Wike, L. D., R. W. Shipley, A. L. Bryan, Jr., J. A. Bowers, C. L. Cummins, B. R. del Carmen, G. P. Friday, J. E. Irwin, J. J. Mayer, E. A. Nelson, M. H. Paller, V. A. Rogers, W. L. Specht, and E. W. Wilde. 1994. SRS Ecology: Environmental Information Document. WSRC-TR-93-496, Westinghouse Savannah River Company, Savannah River Site, Aiken, SC.

Wilde, E. W. 1985. Compliance of the Savannah River Plant P-Reactor Cooling System With Environmental Regulations. Demonstrations in Accordance With Sections 316(a) and (b) of the Federal Water Pollution Control Act of 1972. Report No. DP-1708. E. I. duPont de Nemours and Company, Savannah River Laboratory, Aiken, SC.

Winn, W, G. 1993. Measurements of Radionuclides in Par Pond Sediments with an Underwater HPGE Detector (U). WSRC-TR-93-0209. Westinghouse Savannah River Company, Aiken, SC.

Wright, S. R. 1994. "National Environmental Policy Act (NEPA) Flow Requirements for Steel Creek Below L-Lake Dam (U)." Interoffice Memorandum, S. R. Wright to J. S. Roberts, Department of Energy, Savannah River Operations Office, Aiken, SC.

WSRC (Westinghouse Savannah River Company). 1992. Baseline Risk Assessment Using Existing Data for Par Pond. WSRC-RP-91-1197, Westinghouse Savannạh River Company, Aiken, SC. 
WSRC (Westinghouse Savànnah River Company). 1994. Interim Action Proposed Plan for the Par Pond Unit. WSRC-RP-92-1170, Rev. 1. Westinghouse Savannah River Company, Savannah River Site, Aiken, SC.

WSRC (Westinghouse Savannah River Company). 1995. Interim Action Record of Decision, Remedial Alternative Selection (U). Par Pond Unit. WSRC -RP-931549, Savannah River Site, Aiken, SC. 